\title{
Chicago Transit Authority Train Noise Exposure
}

\author{
BY \\ LINH THUY PHAN \\ BS, Hanoi School Of Public Health, 2012
}

THESIS

Submitted as partial fulfillment of the requirements

for the degree of Master of Science in Public Health Sciences in the Graduate College of the

University of Illinois at Chicago, 2015

Chicago, Illinois

Defense Committee:

Rachael Jones, Chair and Advisor

Lisa Brosseau

Salvatore Cali 


\section{ACKNOWLEGEMENTS}

First of all, I would like to express my deepest gratitude to my advisor, Dr. Rachael Jones, for her great support of my study and research, for her enthusiasm, motivation, and immense knowledge. Her guidance helped me through all the process of my research and writing this thesis. I have been amazingly fortunate to have an advisor like her.

I would like to thank the rest of my thesis committee: Dr. Lisa Brosseau and Mr. Salvatore Cali, for their supports and insightful comments.

I would like to thank all participants who helped me collect data on Chicago Transit Authority trains. Without their support, I could not finish my work.

I also thank the Pilot Project Research Training Grant from the National Institute of Occupational Safety and Health (NIOSH)_-Training Grant Number T42/OH008672.

Last, but not least, I want to send a special gratitude to my loving parents, Binh Phan and Mai Nguyen for their dedication and the many years of support during my studies. Also, I would like to thank my husband Tan for his understanding, support, and encouragement which made this thesis possible. 
I. INTRODUCTION

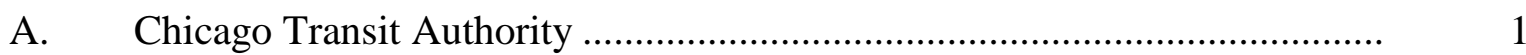

B. Health Impacts of Noise Exposure .......................................................... 2

C. Noise Definition and Measurement ........................................................... 3

1. Noise definition and basic qualities of sound ................................ 3

2. Noise unit and weighting scale ................................................. 4

a. How we hear ....................................................................... 5

b. $\quad$ Noise measurements .......................................................... 5

3. Noise exposure standards........................................................... 8

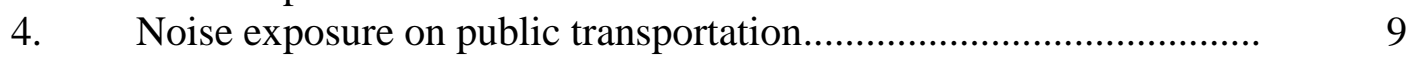

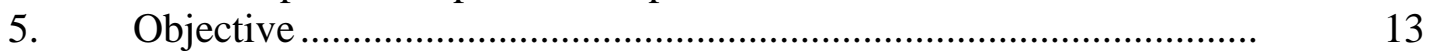

II. METHODS

A. Overview ...................................................................................... 14

B. Participant Recruitment .................................................................... 14

C. Sampling Strategy .................................................................................. 15

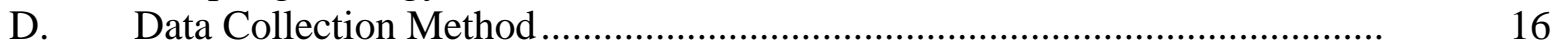

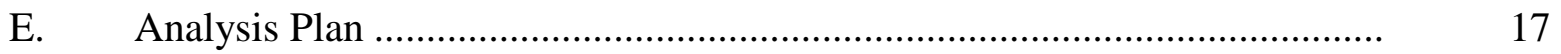

III. RESULTS

A. Summarize Measured Noise Levels on Chicago Transit Authority Trains ...

B. Quantify Differences in Mean Noise Levels among

Chicago Transit Authority Train Line

1. Comparing the 1-minute peak noise levels between train lines.............. 27

2. Comparing the 1-minute average noise levels between train lines.......... 29

C. Calculate and Summarize Noise Levels among

Segments of Each Train Lines ...................................................................... $\quad 30$

D. Identify Factors That Influence Noise Levels on

Chicago Transit Authority Trains....

E. Comparing Noise Level with Standards ............................................. 34

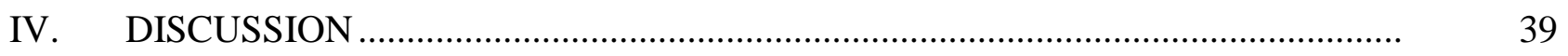

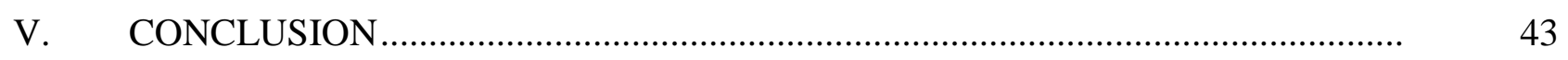

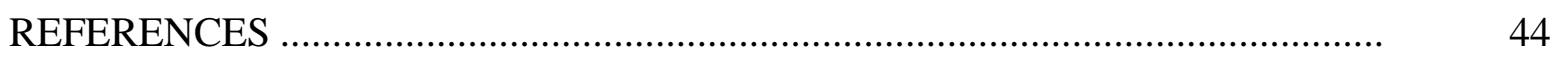

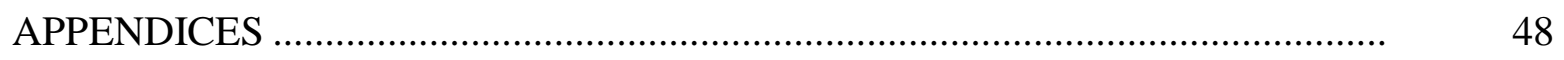

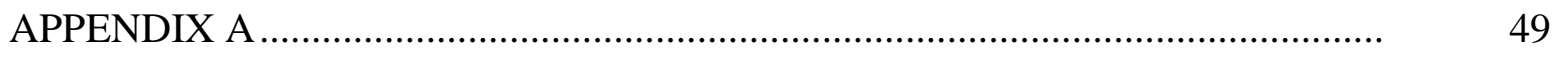

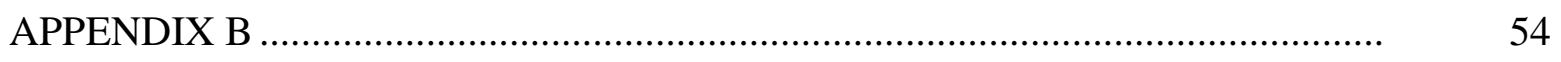

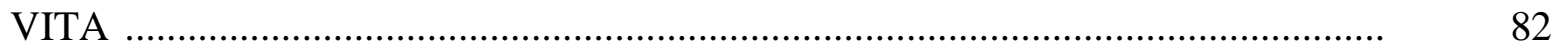




\section{LIST OF TABLES}

$\underline{\text { TABLE }}$

PAGE

I. ALLOWABLE EXPOSURE TIME FOR OSHA PEL, THE NIOSH REL, AND ACGIH TLV TO COMPLY WITH CRITERIA 90 DBA AND 85 DBA, AND USING 5-DBA AND 3-DBA EXCHANGE RATE, RESPECTIVELY

II. NOISE EXPOSURES ASSOCIATED WITH PUBLIC TRANSPORTATION, GLOBALLY

III. SUMMARY OF MEAN AND PEAK 1-MIN NOISE LEVEL (LEQ AND LPEAK) BY TRAIN BRANCH

IV. MEAN AND STANDARD DEVIATION (SD) OF NOISE LEVEL

BY SEGMENT (S.LPEAK AND S.LEQ) BY TRAIN LINE BRANCH

V. LINEAR MIXED-EFFECT MODEL FOR 1-MIN LPEAK AND LEQ

VI. SIGNIFICANT LPEAK AND LEQ CONTRASTS BETWEEN TRAIN LINES, WITH SE ESTIMATES FOR THE DIFFERENCE AND 95\% CIs

VII. SUMMARY OF SEGMENT-NOISE LEVELS BY LOCATION

VIII. LINEAR MIXED-EFFECT MODEL FOR S.LEQ AND S.LPEAK.

IX. LINEAR MIXED-EFFECT MODEL FOR S.LEQ WITH TRAIN RIDE AS A RANDOM EFFECT, TRAIN COLORS AND TRACK LOCATION AS FIXED EFFECTS

X. COMPARISON WITH OSHA AND NIOSH NOISE STANDARDS ................... 36

XI. LINEAR MIXED-EFFECT MODEL FOR SEGMENT-PEAK NOISE LEVELS...... 50

XII. SIGNIFICANT S. LPEAK CONTRASTS BETWEEN TRAIN LINES, WITH SE ESTIMATES FOR THE DIFFERENCE AND 95\% CIs......................... 51

XIII. LINEAR MIXED-EFFECT MODEL FOR SEGMENT-AVERAGE NOISE LEVEL... 52

XIV. SIGNIFICANT S.LEQ CONTRAST BETWEEN TRAIN LINES, WITH SE ESTIMATES FOR THE DIFFERENCE AND 95\% CIs 


\section{LIST OF FIGURES}

1. $\quad$ CTA average daily boarding by lines by Sept. 2013 (CTA, 2014) ......................... 2

2. One-minute average noise level and 1-minute peak noise level by train line .......... 22

3. Segment-average noise level and segment-peak noise level by train line ............... 24

4. Segment-average train noise level and segment-peak noise level by the number

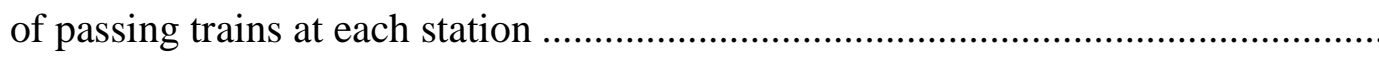




\section{LIST OF ABBREVIATIONS}

ACGIH

$\mathrm{AL}$

BART

CTA

$\mathrm{dB}$

dBA

ER

$\mathrm{Hz}$

Leq

$\mathrm{L}_{\text {peak }}$

$\mathrm{L}_{\max }$

NIHL

NIOSH

OSHA

PEL

REL

SE

SPL

TWA

TLV

UIC

WHO

\section{American Conference of Governmental Industrial Hygienists}

Action Level

Bay Area Rapid Transit

Chicago Transit Authority

Decibel

A-weighted Decibel

Exchange Rate

Hertz

Equivalent continuous noise level/ Average noise level

Peak Noise Level

Maximum Noise Level

Noise-Induced Hearing Loss

National Institute for Occupational Safety

Occupational Safety and Health Administration

Permissible Exposure Limit

Recommended Exposure Limit

Standard Error

Sound Pressure Level

Time-Weighted Average

Threshold Limit Value

University of Illinois at Chicago

World Health Organization 


\section{SUMMARY}

The Chicago Transit Authority (CTA) is the second largest public transport system in the United States, and serves the Chicago metropolitan area and 35 suburbs. Riding CTA trains can be unpleasant due to noise, but it is unclear if the noise is high enough to cause adverse health outcomes for train riders and drivers. The goal of this study is to characterize the noise exposure of riders on the CTA trains and to identify factors influencing noise levels.

Twenty-eight students were recruited to participate in this study. Participants were asked to ride a specific train route while wearing a noise dosimeter and complete a questionnaire about factors that might influence noise levels. Participants rode in the first car, where the driver's cab is located. We used CEL-35x dBadge noise dosimeters, set to integrate sound levels over 1-minute intervals with a $5 \mathrm{~dB}$ exchange rate, an $80 \mathrm{~dB}$ threshold and a $90 \mathrm{~dB}$ criterion. Noise measurements were taken in train car only.

Train drivers have longer duration exposure than riders. The estimated 8-hour noise doses, however, do not exceed the exposure limits. The linear-mixed effect regression models showed that the 1-min and segment-average noise levels of the Blue line, which were about $78 \mathrm{dBA}$, were significantly higher than all the other lines. The segment-average noise level for segments involving travel through tunnels (77dBA) was $2 \mathrm{dBA}$ significantly higher than elevated segments and $3 \mathrm{dBA}$ higher than ground segments.

The Blue line had higher noise levels than other train lines, but noise doses do not exceed occupational exposure limits for ride or 8-hour durations. Train drivers may have different exposures than riders, however, because they are in a cab with operational windows. Future work should confirm that drivers' noise exposures are below exposure limits. 


\section{INTRODUCTION}

\section{A. Chicago Transit Authority}

The Chicago Transit Authority (CTA) is the second largest public transport system in the United States, and serves the Chicago metropolitan area and 35 suburbs. The CTA accounts for $83 \%$ of the public transit trips in the Chicago area. There are eight train lines operated by CTA, named the Red, Blue, Brown, Green, Orange, Purple, Pink, and Yellow Lines. These eight lines travel over 224 miles of track (CTA, 2014). The Red Line travels from Howard Street station at Chicago's northern border, underground through the Loop, and continues south to 95th Street. The Blue Line travels from O'Hare International Airport through the Loop to Forest Park on Chicago's West side. The Green Line travels east from Harlem through the Loop to Ashland and Cottage Grove on Chicago's South side. The Orange, Purple, Pink, and Brown Lines depart from the Loop to Midway International Airport, Linden, 54th and Cermak, and Kimball, respectively. The Red Line has the highest daily ridership (Figure 1), followed closely by the Blue Line.

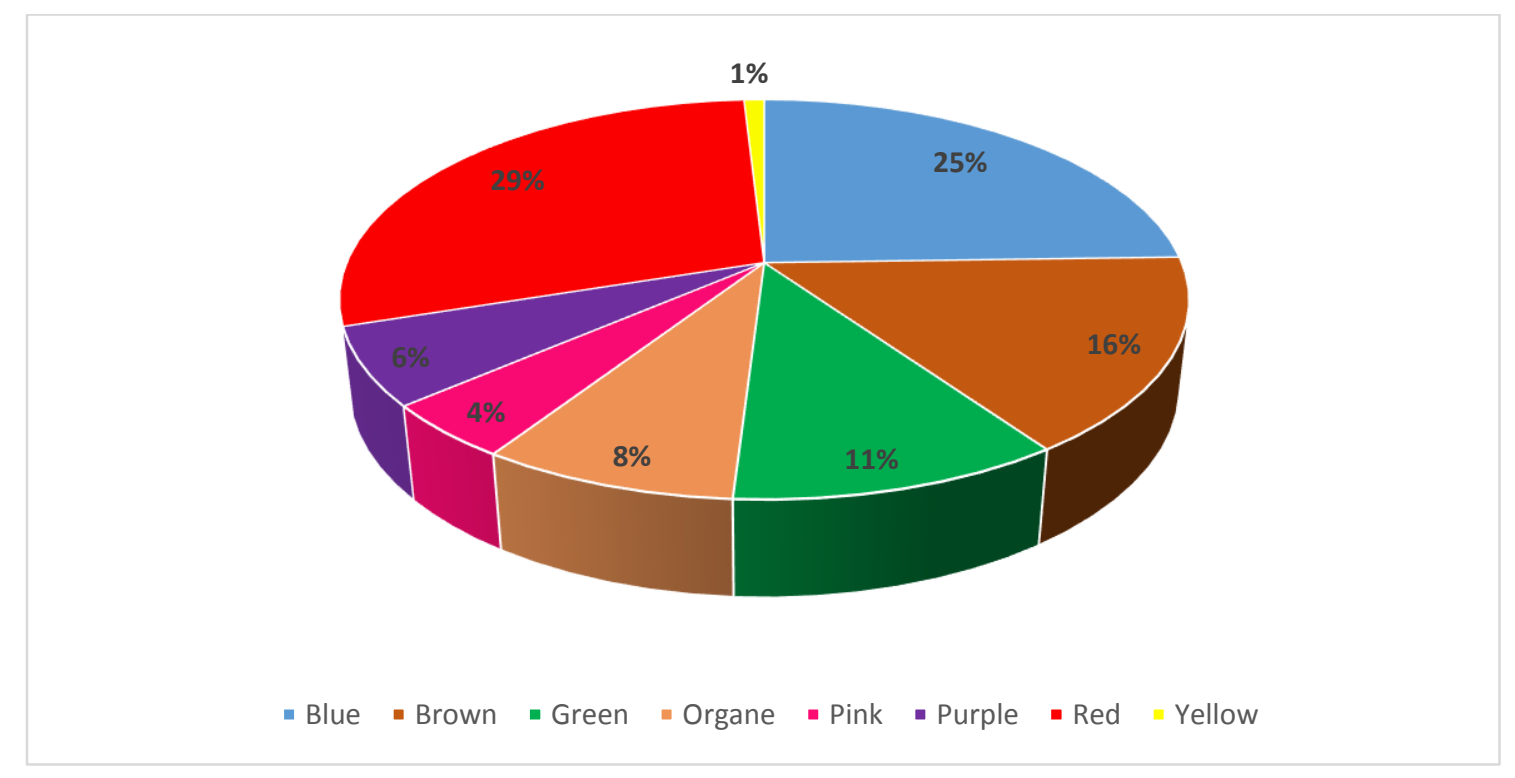

Figure 1. CTA average daily boarding by lines by Sept. 2013 (CTA, 2014). 


\section{B. Health Impacts of Noise Exposure}

The World Health Organization (WHO) estimated that occupational noise causes $16 \%$ of disabling hearing loss in adults worldwide (Nelson et al., 2005). According to the National Institute for Occupational Safety and Health (NIOSH), hearing loss is the most common occupational disease and the second most common self-reported occupational illness or injury in the United States (NIOSH, 2011). There are approximately twenty-two million workers who are exposed to hazardous noise among United States industries. Masterson et al. found the prevalence of hearing loss among workers in the transportation and support industry was 13.24\% (Masterson et al., 2013).

There are several types of hearing loss, only some of which are the result of noise exposure. Hearing loss can be caused by the ageing process, which is termed presbyacusis. Nosoacusis is hearing loss attributable to all other causes such as mumps, rubella, and ototoxic drugs (AIHA 2013). Noise-induced hearing loss (NIHL) can result from occupational and nonoccupational exposure to noise; that due to nonoccupational noise exposure to noise is called sociacusis (AIHA 2013). Both NIHL and presbyacusis can be distinguished in audiometric testing because they impact hearing sensitivity at different frequencies.

The NIHL is caused by exposure to sound levels that damage the hair cells of cochlea, and can cause a permanent or temporary threshold shift in hearing sensitivity. Temporary threshold shift is a decrease in hearing sensitivity and can be recovered within a few minutes or hours, but permanent threshold shift is irreversible (NIOSH 1998). The NIHL occurs predominantly at higher frequencies, 3,000 (Hertz) $\mathrm{Hz}$ and 6,000 $\mathrm{Hz}$, with the most potent effect at 4,000 $\mathrm{Hz}$. This is different from presbyacusis, which produces hearing loss at high frequencies in a down-sloping pattern (Kirchner et al., 2012). 
Noise can cause annoyance, which is defined by the WHO (2004) as "a feeling of resentment, displeasure, discomfort, dissatisfaction, or offense which occurs when noise interferes with someone's thought, feelings, or daily activities." There is evidence that populations exposed to sound levels of 37 A-weighted decibels (dBA) for more than a year have annoyance, and have severe annoyance when exposed to sound levels of around $42 \mathrm{dBA}$ for more than a year (WHO 2004).

Limited epidemiologic evidence suggests that noise exposure may cause chronic illness. A cohort study by Sorensen et al. on noise exposure and breast cancer concluded that a 10-decibel (dB) increase in railway noise significantly increased the risk of estrogen receptor negative breast cancer among women aged 50-64 years (Sorensen et al., 2014). Noise exposure may also cause adverse cardiovascular effects (Babisch et al., 1999; Banerjee et al., 2013).

\section{Noise Definition and Measurement}

\section{1. $\quad$ Noise definition and basic qualities of sound}

Occupational noise can be caused by any sound in the work environment. Sound propagates as a wave of pressure disturbances that travel through any elastic medium (OSHA, 2013). Sound pressure is the magnitude of the pressure disturbances, or vibrations. The range of sound pressure is very large. Low sound pressure can cause faint sounds. High sound pressure can cause loud noise, and can cause pain. Sound pressure level, $\mathrm{L}_{\mathrm{p}}$, is the sound pressure, $\mathrm{P}$, relative to the reference sound pressure, $\mathrm{P}_{0}=20 \mu \mathrm{Pa}$, and has units of decibel, $\mathrm{dB}$ (AIHA 2003):

$$
\mathrm{L}_{\mathrm{p}}=20 \log \left(\mathrm{P} / \mathrm{P}_{0}\right)
$$

The reference sound pressure is the threshold of normal human hearing at 1,000 Hz. 
Sound frequency, $\mathrm{f}$, is a measure of sound pressure cycles that occur per second $(\mathrm{Hz})$. Sound frequency is perceived as pitch (AIHA 2003).

Sound power is the amount of energy per unit time radiating from a source and is usually measured in watts. Sound power level, $\mathrm{L}_{\mathrm{w}}$, is the sound power, W, relative to the reference sound pressure, $\mathrm{W}_{0}=10^{-12}$ watts, and has the units of decibel, dB (AIHA 2003):

$\mathrm{L}_{\mathrm{w}}=10 \log \left(\mathrm{W} / \mathrm{W}_{\mathrm{o}}\right)$

Noise intensity is heard as loudness. Loudness is the human response to sound and it depends on sound pressure and frequency (OSHA 2013).

Noise can be continuous, intermittent, or impulsive. If the variations in noise level involve maxima at intervals of one second or less, it can be considered as continuous. Intermittent noise is a mixture of relatively quiet and noisy periods. Impulsive noise is a very loud noise that lasts less than one second. According to the Occupational Health and Safety Association (OSHA) monitoring requirements, all continuous, intermittent, and impulsive noise from $80 \mathrm{~dB}$ to $130 \mathrm{~dB}$ are integrated by noise measurement devices (OSHA, 2015, CCOHS, 2015).

\section{Noise unit and weighting scale}

$\mathrm{A} \mathrm{dB}$ is the unit to measure sound. One $\mathrm{dB}$ is the minimum difference in sound loudness that is often noticeable. Decibel is:

$$
\mathrm{L}=10 \log (\mathrm{A} / \mathrm{B})
$$

where $\mathrm{L}$ is the sound loudness, $\mathrm{A}$ is sound power, and $\mathrm{B}$ is a reference quantity of $10^{-12} \mathrm{~W}$ (AIHA, 2003). The upper end of human hearing occurs at sound pressure 10 million times the human hearing threshold. Thus, the $\mathrm{dB}$ scale is used because it can compress the noise range relevant to human hearing to a more manageable range. 
In regard to noise monitoring instruments, three weighting filters $(\mathrm{A}, \mathrm{B}$, and $\mathrm{C})$ have been used to estimate equal loudness perception of human hearing for pure tones. The dBA approximates the equal loudness response of human hearing to different sound pressure levels (SPLs) relative to the references of SPL at $40 \mathrm{~dB}$ and frequency $1,000 \mathrm{~Hz}$. In other words, the $\mathrm{dBA}$ is characterized by 40-phon-equal-loudness contour. Similarly, B-weighted and C-weighted scales are characterized by 70-phon and 100-phon-equal-loudness contours, respectively. The C-weighted sound level measurements are not really different from A-weighted sound level measurement unless the measured sound has frequency below $25 \mathrm{~Hz}$ or above $10,000 \mathrm{~Hz}$. Comparison of the three weighting filters found the $\mathrm{dBA}$ better characterizes health risk than the two other filters. Therefore, Aweighted sound level is widely accepted and used in many noise regulations (AIHA, 2003). In this study, noise will be measured using the A-weighted scaling to best represent human ear sensitivity.

\section{a. How we hear}

The function of the ear involves three stages. The first stage includes modification of the acoustic waves by the outer ear, which directs the waves to the tympanic membrane or eardrum. The second stage is the conversion and amplification of the modified acoustic wave to the vibration of the eardrum that is amplified by the ossicles and transmits sound pressure through the middle ear to the inner ear. The last stage is the transformation of the mechanical movement of the acoustic wave into nerve impulses. The brain perceives and interprets the nerve impulses as sound (OSHA 2013).

\section{b. $\quad$ Noise measurements}

Equivalent continuous noise level, denoted $\mathrm{L}_{\mathrm{eq}, \mathrm{T}}$, is the average noise level over the sample time. However, since the $\mathrm{dB}$ is a logarithm, instantaneous measures of noise level cannot be arithmetically averaged. Instead, Leq,T is calculated: 
Leq, $=10 \log \left[\frac{1}{T} \int_{0}^{T} 10^{L A(t) / 10} d t\right](1)$

where $\mathrm{L}_{\mathrm{A}(\mathrm{t})}$ is A-weighted noise level as a function of time (AIHA, 2003). The maximum noise level, $\mathrm{L}_{\max }$ or $\mathrm{L}_{\text {peak }}$ is the highest noise level during the sample time-e.g., the maximum value of $\mathrm{L}_{\mathrm{A}}(\mathrm{t})$. Average sound level can also be reported as time-weighted average (TWA), which is a long-term average, typically over an 8-hour time period.

Noise exposure limits consider both the magnitude and duration of exposure. Noise intensity and duration are believed to be directly correlated to hearing damage, so regulatory and advisory agencies generally allow a doubling of noise intensity when the duration of exposure is halved, and vice versa. The exchange rate (ER) is the relationship between the change in the allowable exposure time and the increase or decrease in noise level. The $\mathrm{dB}$ scale is logarithmic, so a doubling of sound power occurs when sound intensity increases by $3 \mathrm{~dB}$. The OSHA uses a 5-dB exchange rate (OSHA, 2013), while the American Conference of Governmental Industrial Hygienists (ACGIH) and NIOSH use 3-dB exchange rate (NIOSH, 1998). The difference in exchange rates among NIOSH/ACGIH and OSHA results in a markedly increased difference is dose and allowable exposure duration as noise intensity increases. For example, assuming that the duration of exposure is the same, a dose of $90 \mathrm{~dB}$ is twice the dose of $85 \mathrm{~dB}$ when using a 5-dB ER. If 3-dB ER is used, a dose of $90 \mathrm{~dB}$ is twice the dose of $87 \mathrm{~dB}$ instead.

Noise dose, D, in percent, is calculated according to the following formula:

$\mathrm{D}=\left(\sum_{i=1}^{n} \frac{C_{i}}{T_{i}}\right) \times 100(2)$ 
where $\mathrm{n}$ is the number of noise values, $\mathrm{C}_{\mathrm{i}}$ is the total time of exposure at a specific noise level, and $\mathrm{T}_{\mathrm{i}}$ is the allowable exposure time for that noise level based on the policies of NIOSH, ACGIH, or OSHA. In this study noise levels were recorded every minute, so $\mathrm{C}_{\mathrm{i}}=1$ minute.

The noise dose (Equation 1) is used to calculate the 8-hour TWA sound level. As specified by OSHA, the calculation is:

$\mathrm{TWA}=16.61 \log _{10}(\mathrm{D} / 100)+90(3)(\mathrm{OSHA} 2013)$

As specified by NIOSH and ACGIH, the calculation is:

$\mathrm{TWA}=10 \log _{10}(\mathrm{D} / 100)+85(4)(\mathrm{NIOSH} 1998)$

Equations 2 and 3 differ because OSHA uses exchange rate of $5 \mathrm{dBA}$ and noise criteria of $90 \mathrm{dBA}$ while NIOSH and ACGIH uses $3 \mathrm{dBA}$ exchange rate and noise criteria of $85 \mathrm{dBA}$.

The instrument used to measure noise exposure is a dosimeter. Dosimeters may be fixed in place, hand-held, or worn on the body. Dosimeters measure SPL and integrate or average sound over a period of time. In this study, a body-worn dosimeter was used to quantify sound-level measurement. One-minute integrated and peak sound pressure levels were recorded.

Audiometry testing is used to monitor a person's hearing over time. Tested frequency range is from 250 to $8,000 \mathrm{~Hz}$. According to OSHA, an employer has to implement an audiometric testing program. The test can be conducted by either professionals and trained technicians. Also, it is required that employers need to implement a hearing conversation program if their employees are exposed to 8-hour TWA of $85 \mathrm{dBA}$ or greater. Noise monitoring in the workplace can estimate the noise exposure of employees and determine if exposures are at or above this level. 


\section{Noise exposure standards}

The OSHA permissible exposure limit (PEL) for noise is $90 \mathrm{dBA}$, as an 8-hour TWA. In addition, OSHA requires employers to administer a hearing conversation program when employees are exposed to noise levels at or above an 8-hour TWA of $85 \mathrm{dBA}$, the action level. The OSHA action level uses criterion level of $90 \mathrm{dBA}$, a threshold level of $80 \mathrm{dBA}$, and an exchange rate of 5dBA. The OSHA PEL has the same criteria as the action level except for the threshold of $90 \mathrm{~dB}$ (OSHA, 2013).

The NIOSH recommended exposure limit (REL) is $85 \mathrm{dBA}$, as an 8-hour TWA. The NIOSH uses a criterion level of $85 \mathrm{dBA}$, a threshold level of $80 \mathrm{dBA}$, and an exchange rate of $3 \mathrm{dBA}$ (NIOSH 1998). Table I describes the OSHA, NIOSH, and ACGIH allowable exposure times at the exposure limit. Note that the ACGIH Threshold Limit Value (TLV) is identical to the NIOSH REL. 


\section{TABLE I}

ALLOWABLE EXPOSURE TIME FOR OSHA PEL, NIOSH REL, AND ACGIH TLV TO COMPLY WITH CRITERIA LEVELS 90 DBA AND 85 DBA, AND USING A 5-DBA AND 3 DBA EXCHANGE RATE, RESPECTIVELY.

\begin{tabular}{|c|c|c|c|}
\hline \multirow{2}{*}{$\begin{array}{c}\text { Sound Pressure } \\
\text { Level (dBA) }\end{array}$} & \multicolumn{3}{|c|}{ Allowable Duration of Exposure (hours) } \\
\cline { 2 - 4 } & OSHA PEL & NIOSH REL & ACGIH TLV \\
\hline 75 & $>24$ & $>24$ & $>24$ \\
\hline 85 & 16 & 8 & 8 \\
\hline 90 & 8 & 2.52 & 2.52 \\
\hline 100 & 2 & 0.25 & 0.25 \\
\hline 105 & 1 & 0.08 & 0.08 \\
\hline 115 & 0.25 & 0.008 & 0.008 \\
\hline
\end{tabular}

\section{4. $\quad$ Noise exposure on public transportation}

Despite the heavy utilization of public transportation in urban areas, there has been

limited research about the magnitude of noise exposure among drivers and riders. Most intra-city or regional trains are separate from intercity or national commuter trains, and may use different technology. Intra-city trains often operate over shorter distances than railways, and therefore tend to have more stops and a quick braking system, while intercity trains tend to slowly reduce their speed. In the Chicago area, for example, the CTA trains provide service primarily to the city of Chicago on dedicated tracks, while the Metra trains provide intercity service and may share tracks with freight trains. 
Previous studies of noise in public transit systems in the United States were conducted in New York and the San Francisco Bay Area. Table II summarizes noise levels associated with public transportation globally.

In New York City, Neitzel et al. (2009) measured noise exposure in 30 subway train lines, 6 railways, and 13 bus lines. The average noise level inside subway train cars, Leq, was $79.3 \mathrm{dBA}$, while the average maximum level, $\mathrm{L}_{\max }$ was $90.5 \mathrm{dBA}$. Almost $20 \%$ of the time, noise level was above $85 \mathrm{dBA}$, and two subway lines had $\mathrm{L}_{\mathrm{eq}}$ greater than $85 \mathrm{dBA}$. This suggests that the noise exposure of train drivers might exceed the OSHA Action Level of $85 \mathrm{dBA}$ over an 8-hour work shift. Neitzel et al. (2009) also found that $\mathrm{L}_{\mathrm{eq}}$ on the MTA subway was higher underground than above ground; though, when underground, $\mathrm{L}_{\mathrm{eq}}$ was lower inside the train car than on the platform.

In California, Dinno et al. (2011) measured noise levels repeatedly on individual segments of the Bay Area Rapid Transit (BART) between two stations. A total of $268 \mathrm{~L}_{\mathrm{eq}}$ measurements were

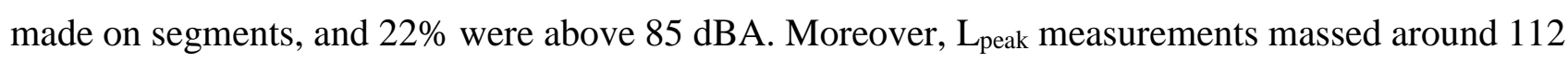
$\mathrm{dB}$, with three exceeding $140 \mathrm{~dB}$, the threshold of impulsive noise recommended by OSHA (OSHA, 2015). The investigation estimated that riders are exposed, at a minimum, around $60 \mathrm{~min} / \mathrm{day}$ at $\mathrm{L}_{\mathrm{eq}} \geq$ $70 \mathrm{dBA}$ and about $20 \mathrm{~min} /$ day at $\mathrm{L}_{\mathrm{eq}} \geq 85 \mathrm{dBA}$ when the trains are in motion. This study found train speed was associated with the average noise level but not associated with the peak noise level. In addition, the average noise level was significantly higher on segments enclosed by tunnels.

While the Neitzel et al. and Dinno et al. studies considered the noise experience of passengers, the only study focused on drivers was performed by Malleson et al. (1989), who measured the exposure of drivers in the London Transport Underground. Malleson et al. (1989) found noise exposures, as an 8-hour TWA, were less than $85 \mathrm{dBA}$. 
TABLE II

NOISE EXPOSURES ASSOCIATED WITH PUBLIC TRANSPORTATION, GLOBALLY

\begin{tabular}{|c|c|c|c|c|c|c|c|}
\hline Population & Location & Vehicle & $\begin{array}{c}\text { Measurement } \\
\text { Type }\end{array}$ & $\begin{array}{c}\text { Measurement } \\
\text { Duration }\end{array}$ & $\begin{array}{c}\text { Range or } \\
\text { Average } \\
\text { (dBA) }\end{array}$ & $\begin{array}{c}\text { Related health } \\
\text { impacts }\end{array}$ & References \\
\hline Bus Drivers & $\begin{array}{l}\text { Curitiba City, } \\
\text { Brazil }\end{array}$ & $\begin{array}{l}\text { Local } \\
\text { conventional } \\
\text { buses }\end{array}$ & $\mathrm{L}_{\mathrm{EX}} *$ & 8 hours & 78.98 & $\begin{array}{l}28 \% \text { claimed } \\
\text { high annoyance }\end{array}$ & $\begin{array}{l}\text { (Bruno et } \\
\text { al., 2013) }\end{array}$ \\
\hline $\begin{array}{l}\text { Train Drivers } \\
\text { and } \\
\text { Conductors }\end{array}$ & Norway & $\begin{array}{l}\text { Regional } \\
\text { train }\end{array}$ & TWA & 8 hours & $70-85$ & $\begin{array}{l}\text { No work-related } \\
\text { hearing loss } \\
\text { observed }\end{array}$ & $\begin{array}{l}\text { (Lie et al., } \\
\text { 2013) }\end{array}$ \\
\hline $\begin{array}{l}\text { Underground } \\
\text { Train Drivers }\end{array}$ & $\begin{array}{l}\text { Victoria line } \\
\text { Train, United } \\
\text { Kingdom }\end{array}$ & Local train & $\mathrm{L}_{\mathrm{eq}}$ & 8 hours & 83.5 & $\mathrm{NA}$ & $\begin{array}{l}\text { (Malleson, } \\
\text { 1989) }\end{array}$ \\
\hline
\end{tabular}


NOISE EXPOSURES ASSOCIATED WITH PUBLIC TRANSPORTATION, GLOBALLY

\begin{tabular}{|c|c|c|c|c|c|c|c|}
\hline Population & Location & Vehicle & $\begin{array}{c}\text { Measurement } \\
\text { Type }\end{array}$ & $\begin{array}{c}\text { Measurement } \\
\text { Duration }\end{array}$ & $\begin{array}{c}\text { Range or } \\
\text { Average } \\
\text { (dBA) }\end{array}$ & $\begin{array}{c}\text { Related health } \\
\text { impacts }\end{array}$ & References \\
\hline $\begin{array}{l}\text { Residential } \\
\text { Neighborhoods } \\
\text { Near Railways }\end{array}$ & $\begin{array}{l}\text { At railroad crossings } \\
\text { and inside the home of } \\
\text { residents, Brazil }\end{array}$ & $\begin{array}{l}\text { Regional } \\
\text { railway } \\
\text { traffic }\end{array}$ & $\mathrm{L}_{\mathrm{eq}}$ & N/A & 80-92*** & $\begin{array}{l}\text { Irritability, } \\
\text { headache, poor } \\
\text { concentration and } \\
\text { insomnia }\end{array}$ & $\begin{array}{l}\text { (Zannin et } \\
\text { al., 2014) }\end{array}$ \\
\hline Train Riders & $\begin{array}{l}\text { In Vehicle and } \\
\text { Platforms or Terminals, } \\
\text { New York }\end{array}$ & $\begin{array}{l}\text { Local } \\
\text { subways }\end{array}$ & Leq & N/A & $79.4-80.4$ & NA & $\begin{array}{l}\text { (Neitzel et } \\
\text { al., 2009) }\end{array}$ \\
\hline Train Riders & $\begin{array}{l}\text { In vehicle, Bay Area } \\
\text { Rapid Transit Trains, } \\
\text { San Francisco }\end{array}$ & $\begin{array}{l}\text { BART } \\
\text { train line }\end{array}$ & Leq & $\begin{array}{l}\text { Sound level was } \\
\text { integrated over } \\
\text { 1-min interval }\end{array}$ & 83 & NA & $\begin{array}{l}\text { (Dinno et } \\
\text { al., 2011) }\end{array}$ \\
\hline
\end{tabular}

*** Train passing with horn blowing, the noise levels were measured at the facades of homes closest to the rail way.

* $\mathrm{L}_{\mathrm{EX}, 8 \mathrm{~h}}$ is the $\mathrm{L}_{\mathrm{eq}}$ - Equivalent Continuous Sound Level corrected for the length of the working shift in 8 hours (Acoustic Glossary, 2015 


\section{5. $\quad$ Objective}

The objective of this study was to characterize the noise exposure of riders on CTA trains. To our knowledge, this is the first study of noise levels on Chicago public transit. Research in New York City and the San Francisco Bay Area suggests that riders may experience high noise levels while riding trains. Based on these studies, the noise exposure of riders in Chicago is not likely to approach the 8-hour TWA occupational exposure limits of OSHA, NIOSH, and ACGIH, but peak exposures may exceed $147 \mathrm{~dB}$ (Dinno et al., 2011). These peak exposures may put riders at risk for hearing damage, particularly if they have additional noise exposures, and suggest that quantification of noise exposures on CTA trains is an important environmental and occupational hazard.

Findings of high noise exposure for riders may indicate the potential for an occupational hazard among train drivers, who have longer duration exposures; and may inform policy makers and CTA about the likelihood of annoyance and discomfort among riders. This research will contribute to our understanding of the magnitude and determinants of urban noise exposures. The specific objectives are:
A. Summarize measured noise levels on CTA trains.
B. Quantify differences in mean noise levels among CTA train lines, if any.
C. Calculate and summarize noise levels among segments of each train line.
D. Identify factors that influence noise levels on CTA trains, if any.
E. Assess the risk of noise-induced hearing loss associated with riding CTA trains. 


\section{METHODS}

\section{A. $\quad \underline{\text { Overview }}$}

The general approach to data collection was to ask participants to ride CTA train lines while wearing a noise dosimeter, and to complete a short questionnaire about features of the train and train ride that might influence noise levels. Participants were asked to ride a specific train route, and to sit in the first car. Participant ridership resulted in monitoring of seven of the eight lines at least four times each. The Yellow Line - to Skokie_-was not included because it is short and has relatively low ridership (Figure 1). Since riding the complete length of some train lines required more than two hours, participants rode half of the route (e.g., from downtown to one end of the Red Line). The noise dosimeter data and questionnaire were used to address all study objectives.

We use the following terms to describe portions of the CTA train system:

- The term train line refers to the seven train lines, defined by their colors.

- The term train branch refers to the length of a train line extending from the Loop to a terminus. For example, the Blue line has two branches extending from the Loop to O'Hare International Airport and from the Loop to Forest Park. The Red and Green lines also have two branches, while the Pink, Brown, Purple, and Orange lines have one branch.

- The term train segment refers to the distance between two stations. Each train segment was classified as being primarily underground, aboveground and elevated.

\section{B. $\quad$ Participant Recruitment}

Participants were recruited by sending referral via the University of Illinois at Chicago (UIC) online mailing service and signs posted around UIC. Recruitment materials specified that participants needed to wear a noise dosimeter and answer a questionnaire. Consent forms were distributed to the participants before they participated into the study, and participants were asked to 
give verbal consent to participate. This study was approved by the UIC Institutional Review Board, research protocol 2014-0602.

Participation was incentivized with a $\$ 40$ gift card. The value of $\$ 40$ was judged appropriate because participants spent approximately two hours riding the train, during which time they must complete a questionnaire, and spend additional time collecting and returning the dosimeter. Participants were not specifically reimbursed for the CTA fare (\$2.25), as many participants have a U-Pass or other CTA pass, and the participation incentive exceeds the CTA fare.

\section{Sampling Strategy}

Noise levels on seven of the eight train lines were measured four times. We chose a minimum of four samples on each train line to ensure sufficient sample size of quantifying exposure variability. We recruited at least four participants for each train line route. Since riding the complete length of some train lines required more than two hours, participants rode half of the route (e.g., from downtown to one end of the Red Line). We did not sample the Yellow Line since there are a small number of riders on this line compared to other lines (Figure 1). Ultimately, we had 28 samples among 7 train lines.

We considered allocating the samples among the train lines based on ridership, to capture the ridership-average noise exposure. However, the noise exposure of the "average" CTA rider is also a function of the section of each train line ridden. Ultimately, we determined that a balanced sampling design would allow us to estimate the ridership-average noise exposure with consideration of ridership of specific train line sections with fewer samples, if that became of interest.

Participants were asked to sit or stand at the middle of the car, consistent with previous studies (Neitzel et al., 2009, Dinno et al., 2011). Participants were asked to ride in the first car of the 
train, to best approximate the experience of the train driver. This also had the effect of eliminating the potential effect of train car position on the noise level.

\section{Data Collection Method}

The noise level meter used is the dBadge CEL 350 (Casella CEL, Inc, Buffalo, New York). These meters measure average and peak sound pressure levels over 60-second intervals, and provide lists and charts of the logged 60 second $\mathrm{L}_{\mathrm{eq}}$ and $\mathrm{L}_{\mathrm{peak}}$, as well as average and peak noise levels for the total time period measured. The dosimeters were calibrated before being given to participants and after being returned. Dosimeters were clipped on participants' clothing while riding the train. Data were downloaded using the manufacturer's software. The following noise metrics were calculated: $\mathrm{L}_{\text {eq }}, \mathrm{L}_{\text {peak }}$, segment $\mathrm{L}_{\text {eq }}$ and $\mathrm{L}_{\text {peak, }}$ single-ride TWA, and 8-hour TWA. The $\mathrm{L}_{\text {eq }}(\mathrm{dBA})$ and $\mathrm{L}_{\text {peak }}(\mathrm{dB})$ parameters are calculated by the noise dosimeter. Segment $\mathrm{L}_{\mathrm{eq}}$ and $\mathrm{L}_{\mathrm{p} e a k}$ are calculated using equation (1). The single-ride TWA sound level (dBA) is calculated using equation (3) and (4). Noise dose for each train ride is calculated using equation (2). We used the single-ride dose to estimate the 8-hour projected dose of the train drivers by the following formula: Single-ride dose $\times 8$ hours $\div$ sampled time.

The questionnaire captured information about factors on the train ride that might influence noise levels, including the arrangement of seats (which indicates the train car model and approximate years of service). In addition, for each segment of the train, participants were asked to record:

- The time of arrival and departure from each station.

- The occupancy level - low (many vacant seats), moderate (most seats full and a few people standing), high (seats full and many people standing), and overfull (crowded standing, like a can of sardines). 
- The occupant activity level—quiet (most people reading or listening to music on headphones), some talking, or loud talking or music.

- The number of passing trains between two stations (segment)

Maps were used to classify the condition of each segment of each train as primarily: elevated, above ground (on a road or berm), or underground.

\section{E. Analysis Plan}

\section{Objective A: Summarize measured noise levels on CTA trains.}

The noise level (Leq, $\mathrm{L}_{\text {peak, }}$, ride-duration TWA, 8h-TWA) was summarized in $\mathrm{dBA}$ or dB, by train line. Standard summary statistics were used to calculate mean values and variance measures. For each train line, we also summarized the noise levels by conditions of the line segments (above ground, underground or elevated). Graphical methods were used to explore patterns in the data, such as boxplots to compare noise levels among train lines.

\section{Objective B: Quantify differences in mean noise levels among CTA train lines, if any.}

We used mixed-effect regression models to compare statistical differences in $\mathrm{L}_{\mathrm{eq}}$ and $\mathrm{L}_{\text {peak }}$ levels among train lines. We used $\alpha=.05$ to define statistical significance. Mixed-effect regression models were used to account for the correlation of noise levels within a train ride.

\section{Objective C: Calculate and summarize noise levels among segments of each train line.}

To attain this objective, the noise level was calculated for each line segment. Time of station arrival and/or departure was used to match the noise-level data to each line segment. For each segment, we calculated $\mathrm{L}_{\text {peak }}$ and $\mathrm{L}_{\mathrm{eq}}$. Summary statistics and mixed-effect regression models were applied to characterize the noise levels in each segment. Graphical methods were also used to explore the data. 


\section{Objective D: Identify factors that influence noise levels on CTA trains, if any.}

We used exploratory data analysis and mixed-effect regression models to determine what factors, if any, influence noise levels on CTA trains. Exploratory data analyses included graphical methods and simple statistics, such a t-tests and correlation coefficients. Factors identified as potentially contributing to noise levels on CTA trains were included as a fixed effect in a mixedeffect regression model. The independent variables were $\mathrm{L}_{\mathrm{eq}}$ and $\mathrm{L}_{\text {peak }}$ measured each minute and by train segment. A unique identifier for train ride was used a random effect to account for repeated measurements.

\section{Objective E: Assess likelihood of noise-induced hearing loss associated with riding CTA}

\section{train lines.}

Since ACGIH TLV and NIOSH REL have the same noise criteria, we tabulated descriptive statistics and compared $\mathrm{L}_{\mathrm{eq}}$ and $\mathrm{L}_{\text {peak }}$ noise doses based on the OSHA PEL and ACGIH TLV. 


\section{RESULTS}

\section{A. Summarize Measured Noise Levels on Chicago Trains}

Table III describes the 1-min average noise level $\left(\mathrm{L}_{\mathrm{eq}}\right)$ and the 1-min peak noise level $\left(\mathrm{L}_{\text {peak }}\right)$ by train branch ( $\left.\mathrm{L}_{\text {peak }}\right)$. For the Blue, Red, and Green Lines, there are two branches from downtown to both end points of each line. The Purple, Orange, Brown and Pink Lines have only one branch from downtown, because the lines depart from the Loop. 


\section{TABLE III}

SUMMARY OF MEAN AND PEAK 1-MINUTE NOISE LEVEL (LQQ AND LPEAK) BY TRAIN BRANCH

\begin{tabular}{|c|c|c|c|c|c|}
\hline \multirow[b]{2}{*}{ Line } & \multirow[b]{2}{*}{ Branch } & \multirow[b]{2}{*}{$\mathbf{N}$} & \multicolumn{2}{|c|}{ Mean (SD) 1-min Noise Level } & \multirow{2}{*}{$\begin{array}{l}\text { Mean (SD) } \\
\text { Duration } \\
\text { (minutes) }\end{array}$} \\
\hline & & & Leq $($ dBA $)$ & $L_{p e a k}(d B)$ & \\
\hline Blue & Downtown $\rightarrow$ O'Hare & 2 & $78.30(3.72)$ & $110.7(3.40)$ & $30(2.82)$ \\
\hline Blue & Downtown $\rightarrow$ Forest Park & 2 & $77.37(3.53)$ & $109.3(3.15)$ & $46.5(6.36)$ \\
\hline Red & Lake $\rightarrow$ Howard & 2 & $72.25(2.69)$ & $107.6(2.69)$ & $40(1.41)$ \\
\hline Red & Lake $\rightarrow 95^{\text {th }}$ Street & 2 & $72.86(1.86)$ & $109.8(4.27)$ & $29(4.24)$ \\
\hline Green & Roosevelt $\rightarrow$ Cottage/Ashland & 2 & $72.83(2.47)$ & $107.7(2.95)$ & $22(4.24)$ \\
\hline Green & Roosevelt $\rightarrow$ Harlem & 2 & $72.15(4.18)$ & $110.0(4.52)$ & $31.5(3.53)$ \\
\hline Purple & Downtown $\rightarrow$ Linden & 4 & $71.23(2.57)$ & $106.9(3.64)$ & $63.75(4.42)$ \\
\hline Orange & Downtown $\rightarrow$ Midway & 4 & $73.41(3.22)$ & $108.6(2.85)$ & $37(1.63)$ \\
\hline Brown & Downtown $\rightarrow$ Kimball & 4 & $72.73(2.33)$ & $109.5(3.90)$ & $50(5.29)$ \\
\hline Pink & Downtown $\rightarrow$ Cermak & 4 & $73.46(3.64)$ & $107.3(3.45)$ & $39.25(3.86)$ \\
\hline
\end{tabular}

The train branches with the highest mean $\mathrm{L}_{\mathrm{eq}}$ are the Blue Line to O'Hare (78.30 dBA), and to Forest Park (77.37 dBA). The lowest mean $\mathrm{L}_{\mathrm{eq}}$ was measured on the Purple Line (71.23 dBA). The mean $\mathrm{L}_{\mathrm{eq}}$ was similar between the two branches of the Red, Blue, and Green Lines, respectively.

Similarly, the highest mean 1-min peak noise level ( $\left.\mathrm{L}_{\text {peak }}\right)$ is on the Blue Line branch from downtown to O'Hare (110.7 dB) and the lowest is on the Purple Line (106.9 dB). The peak noise levels have a similar pattern as the average noise levels. The $\mathrm{L}_{\text {peak }}$ was correlated with $\mathrm{L}_{\mathrm{eq}}$ for all 
train lines $(\mathrm{p}<.05)$. However, the mean $\mathrm{L}_{\text {peak }}$ of the Green Line from Roosevelt to Harlem is particularly high (110.0 dB), and has high variability (standard deviation $4.52 \mathrm{dBA}$ ).

The summary statistics in Table IV are consistent with the graphical presentation in Figure 2, which displays the box-plots of the 1-min average noise level and the 1-min peak noise level by train line. 
1-min Average Noise Level by Train Lines

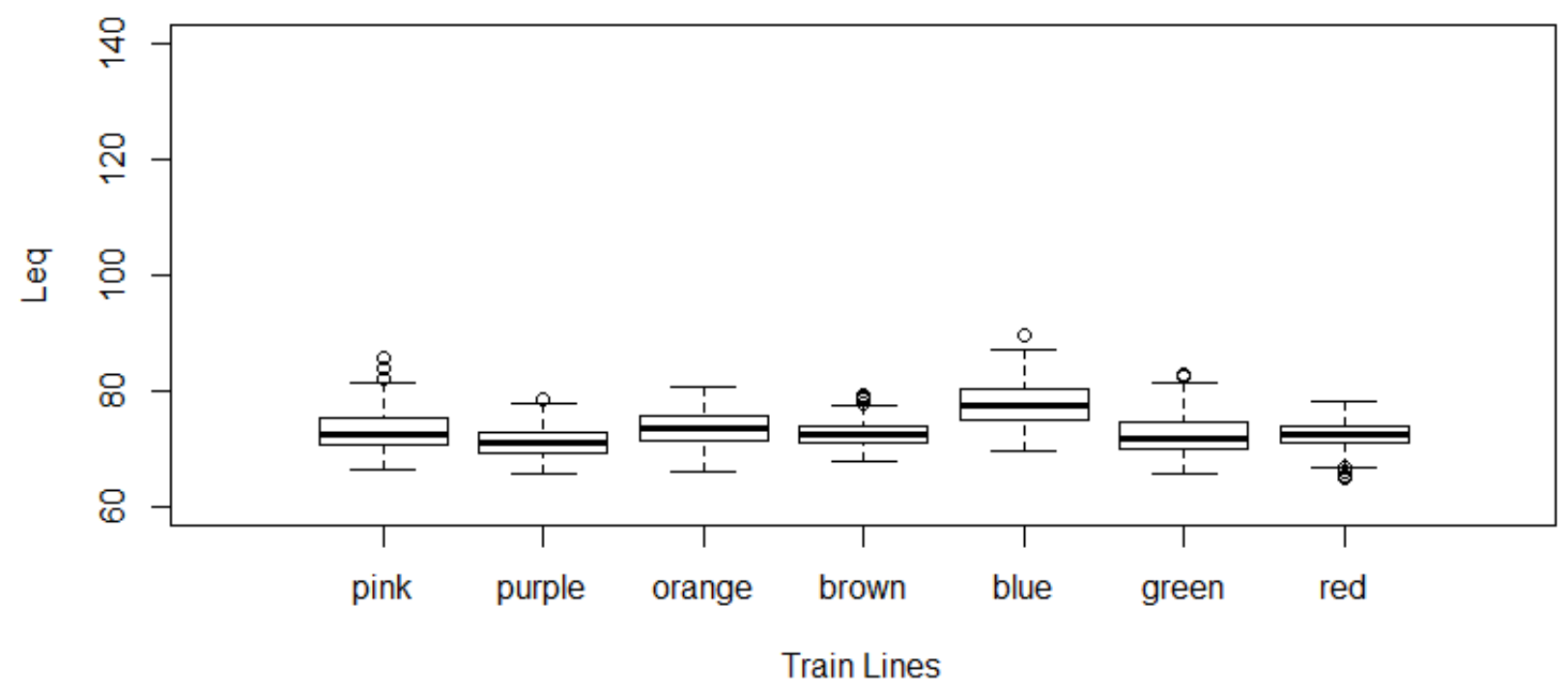

\section{1-min Peak Noise Level by Train Lines}

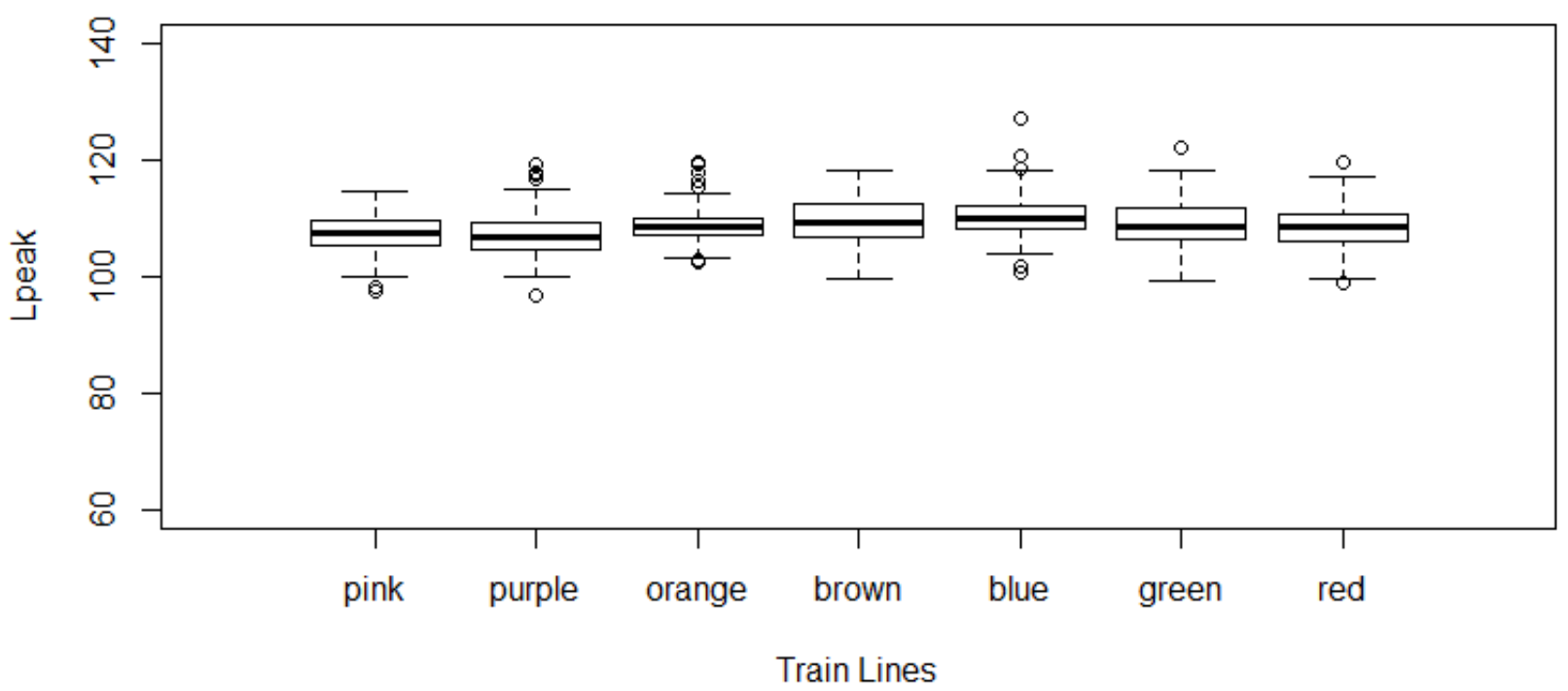

Figure 2. One-min average noise level $\left(\mathrm{L}_{\mathrm{eq}}\right)$ and 1-min peak noise level ( $\left.\mathrm{L}_{\text {peak }}\right)$ by train line. 
Noise levels were tabulated for segments of train lines between stations (Table IV). This table describes the mean of the segment-average noise level (S.Leq) and the mean of the segmentpeak noise level at each station (S.L $L_{\text {peak }}$ ). The mean of S.L $L_{e q}$ and S.L $L_{\text {peak }}$ are highest for the Blue Line branch from downtown to O'Hare (78.87 dBA and $111.0 \mathrm{~dB}$, respectively). The S.Leq and S.Lpeak have the same patterns with the $\mathrm{L}_{\mathrm{eq}}$ and $\mathrm{L}_{\text {peak }}$ (Table III). Figure 3 describes the average noise level and peak noise level at each station by train colors, and is consistent with Table IV.

\section{TABLE IV}

MEAN AND STANDARD DEVIATION (SD) OF NOISE LEVEL BY SEGMENT (S.LPEAK AND S.LEQ) BY TRAIN LINE BRANCH

\begin{tabular}{|c|c|c|c|c|c|}
\hline \multirow[b]{2}{*}{ Line } & \multirow[b]{2}{*}{ Branch } & \multirow[b]{2}{*}{$\mathbf{N}$} & \multicolumn{2}{|c|}{$\begin{array}{c}\text { Mean (SD) Segment Noise } \\
\text { Level }\end{array}$} & \multirow{2}{*}{$\begin{array}{c}\text { Mean (SD) } \\
\text { Duration } \\
\text { (minutes) }\end{array}$} \\
\hline & & & S.Leq $(\mathrm{dBA})$ & S.L $L_{\text {peak }}(d B)$ & \\
\hline Blue & Downtown $\rightarrow$ O'Hare & 2 & $78.87(3.32)$ & $111.0(3.05)$ & $30(2.82)$ \\
\hline Blue & Downtown $\rightarrow$ Forest Park & 2 & $78.13(3.19)$ & $109.9(2.45)$ & $46.5(6.36)$ \\
\hline Red & Lake $\rightarrow$ Howard & 2 & $72.43(2.21)$ & $108.1(2.05)$ & $40(1.41)$ \\
\hline Red & Lake $\quad \rightarrow 95^{\text {th }}$ Street & 2 & $73.17(1.15)$ & $109.9(3.51)$ & $29(4.24)$ \\
\hline Green & Roosevelt $\rightarrow$ Cottage/Ashland & 2 & $73.30(2.21)$ & $108.5(2.45)$ & $22(4.24)$ \\
\hline Green & Roosevelt $\rightarrow$ Harlem & 2 & $72.31(4.05)$ & $110.2(4.48)$ & $31.5(3.53)$ \\
\hline Purple & Downtown $\rightarrow$ Linden & 4 & $72.10(2.45)$ & $107.9(3.58)$ & $63.75(4.42)$ \\
\hline Orange & Downtown $\rightarrow$ Midway & 4 & $73.87(2.95)$ & $108.8(2.38)$ & $37(1.63)$ \\
\hline Brown & Downtown $\rightarrow$ Kimball & 4 & $73.11(2.01)$ & $110.0(3.42)$ & $50(5.29)$ \\
\hline Pink & Downtown $\rightarrow$ Cermak & 4 & $73.72(3.63)$ & $107.28(3.44)$ & $39.25(3.86)$ \\
\hline
\end{tabular}


Segment-Average Noise Level

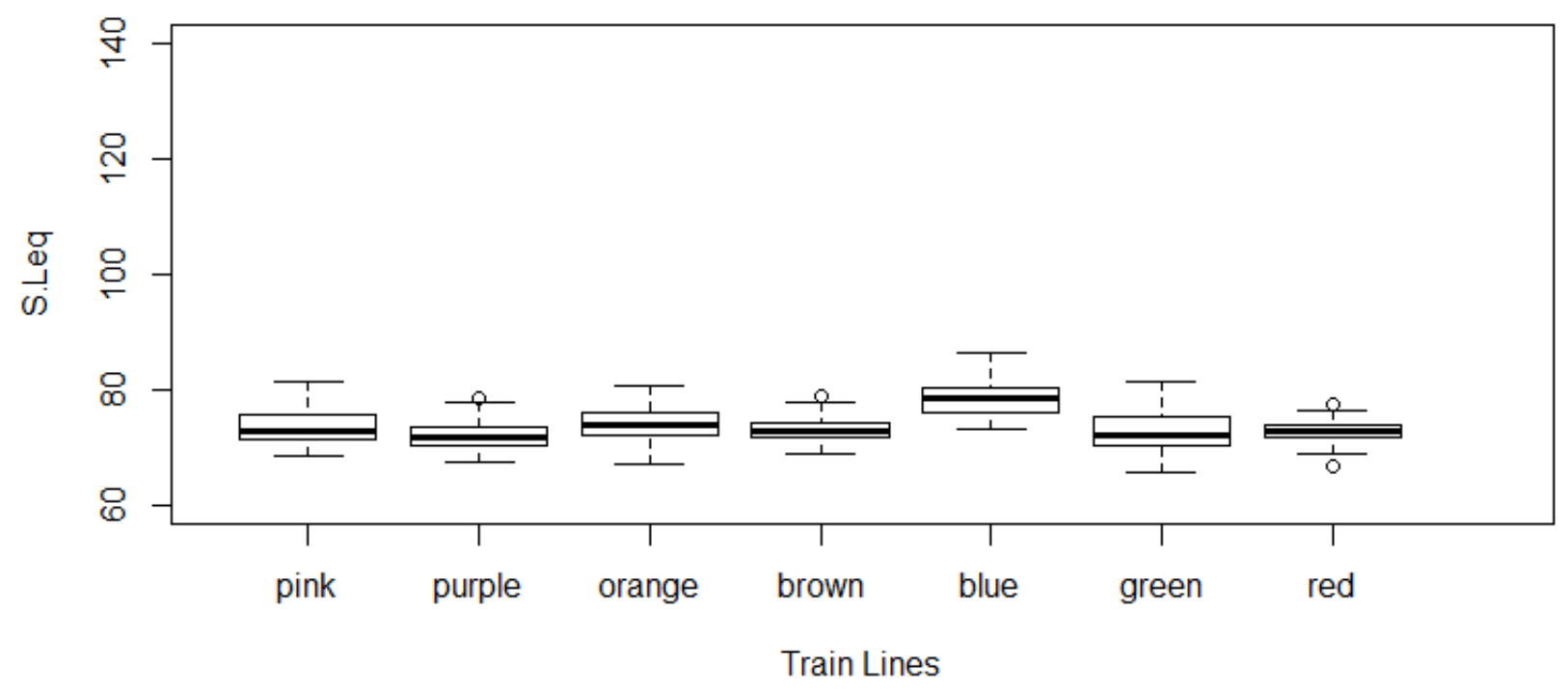

Segment-Peak Noise Level

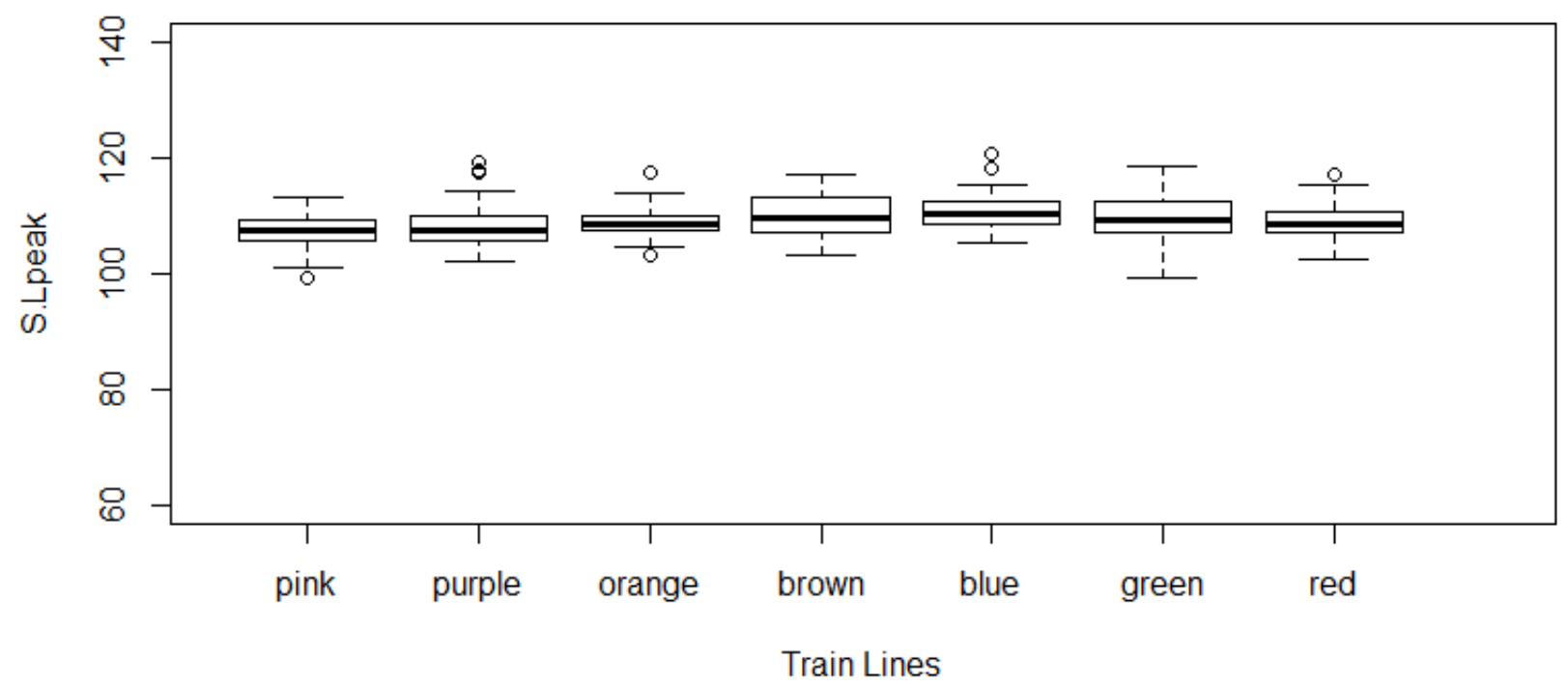

Figure 3. Segment-average noise level (S.Leq) and segment-peak noise level (S.L $L_{\text {peak }}$ by train line. 
The average and peak noise level plotted against the number of passing trains in shown in Figure 4. It was most common that 1-2 trains passed the train ridden by the study participant between stations. There is no visible association between the number of passing trains and the S.Leq and S.Lpeak values (Figure 4). Similar plots were done for occupancy level and occupant activity level but there were no visible associations between S.Leq and S.Lpeak and these variables. As a result, further statistical analyses were not performed. 


\section{Segment-Average Noise Level and Passing Trains}

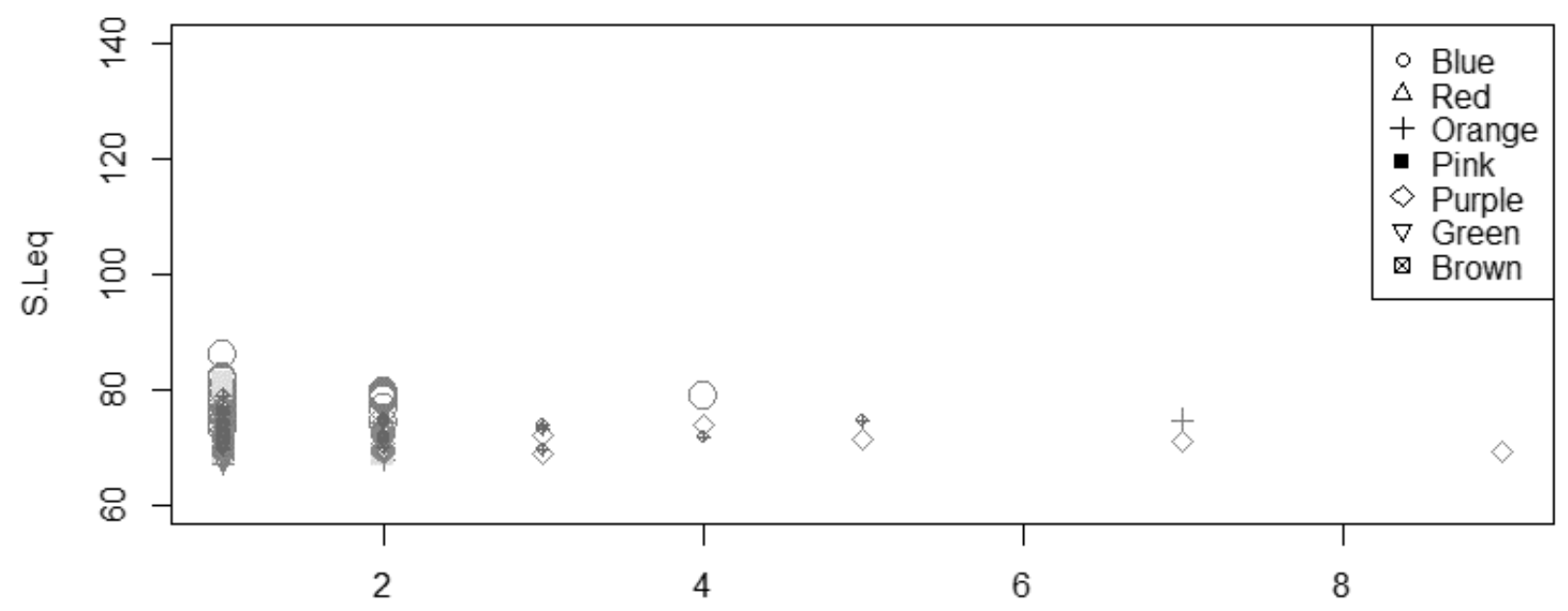

The Number of Train Passing

\section{Segment-Average Noise Level and Passing Trains}

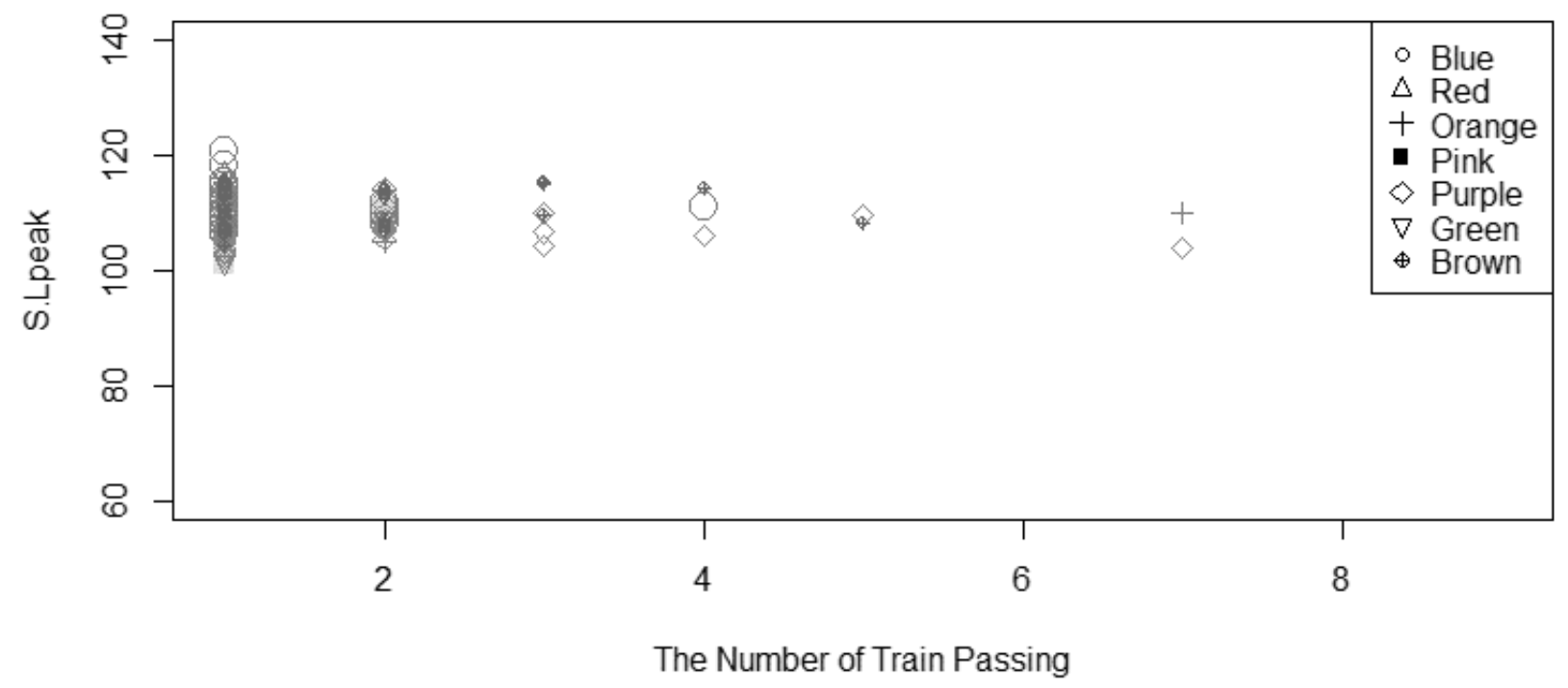

Figure 4. Segment-average train noise level and segment-peak noise level by the number of passing trains at each station. 


\section{B. Quantify Differences in Mean Noise Levels among Chicago Train Lines}

\section{Comparing the 1-minute peak noise levels between train lines}

The 1-min $\mathrm{L}_{\text {peak }}$ values were compared between train lines using a mixed-effect model, with train line as the fixed effect and train ride as the random effect, to account for the repeated noise measurement on each ride (Table V). The intra-class correlation is $22 \%$, indicating that train ride explains $22 \%$ of the variation in the noise levels, after adjusting for the fixed effects. The mean $\mathrm{L}_{\text {peak }}$ levels on the Brown (109.64 dB) and Blue Lines (110.18 dB) are statistically significantly different than the intercept, which is the mean $\mathrm{L}_{\text {peak }}$ levels on the Pink Line, 106.89 $\mathrm{dB}$. The mean $\mathrm{L}_{\text {peak }}$ levels on the Purple, Orange, Green, and Red Lines are higher than the intercept, but the differences are not statistically significant $(\mathrm{p}>.05)$. Other statistically significant contrasts estimated from the 1-min $\mathrm{L}_{\text {peak }}$ regression model in Table V are shown in Table VI. Consistent with Table V, $\mathrm{L}_{\text {peak }}$ of Blue and Brown Lines are significantly higher than $\mathrm{L}_{\text {peak }}$ of Pink Line $(\mathrm{p}<.05)$ (Table VI). In addition, the Blue Line $\mathrm{L}_{\text {peak }}$ is also higher than Purple Line $(\mathrm{p}<.05)$ and the difference is $2.58 \mathrm{~dB}$. 


\section{TABLE V}

LINEAR MIXED-EFFECT MODEL FOR 1-MIN LPEAK AND LEQ

\begin{tabular}{|c|c|c|c|c|c|c|}
\hline & \multicolumn{3}{|c|}{ 1-min $L_{\text {peak }}$} & \multicolumn{3}{|c|}{ 1-min Leq } \\
\hline \multicolumn{7}{|c|}{ Quality of Model Fit: } \\
\hline AIC & \multicolumn{3}{|c|}{2886} & \multicolumn{3}{|c|}{2693} \\
\hline Log Likelihood & \multicolumn{3}{|c|}{-1434} & \multicolumn{3}{|c|}{-1337} \\
\hline \multicolumn{7}{|c|}{ Random effects (SD): } \\
\hline Intercept & \multicolumn{3}{|c|}{1.61} & \multicolumn{3}{|c|}{1.86} \\
\hline Residual & \multicolumn{3}{|c|}{3.07} & \multicolumn{3}{|c|}{2.55} \\
\hline \multicolumn{7}{|l|}{ Fixed effects: } \\
\hline & Value & SE & p-value & Value & SE & p-value \\
\hline Intercept & 106.89 & 0.87 & 0.00 & 73.79 & 0.97 & 0.00 \\
\hline Purple & 0.71 & 1.22 & 0.57 & -1.42 & 1.37 & 0.31 \\
\hline Orange & 1.54 & 1.24 & 0.23 & 0.07 & 1.38 & 0.96 \\
\hline Brown & 2.75 & 1.22 & 0.03 & -0.83 & 1.37 & 0.55 \\
\hline Blue & 3.29 & 1.25 & 0.02 & 4.15 & 1.38 & 0.01 \\
\hline Green & 1.40 & 1.26 & 0.28 & -1.58 & 1.39 & 0.27 \\
\hline Red & 1.52 & 1.24 & 0.24 & -1.54 & 1.38 & 0.28 \\
\hline
\end{tabular}


TABLE VI

SIGNIFICANT LPEAK AND LEQ CONTRASTS BETWEEN TRAIN LINES, WITH SE ESTIMATES FOR THE DIFFERENCE AND 95\% CIs

\begin{tabular}{|l|c|c|c|}
\hline Train Lines Compared & Contrast & SE & 95\% CI \\
\hline Lpeak & 2.58 & 1.24 & $0.14,5.01$ \\
\hline Blue-Purple & 3.29 & 1.25 & $0.84,5.74$ \\
\hline Blue-Pink & 2.75 & 1.22 & $0.35,5.14$ \\
\hline Brown-Pink & & & \\
\hline Leq & 5.69 & 1.39 & $2.95,8.43$ \\
\hline Blue-Red & 5.57 & 1.38 & $2.86,8.28$ \\
\hline Blue-Purple & 4.08 & 1.39 & $1.34,6.82$ \\
\hline Blue-Orange & 4.98 & 1.38 & $2.27,7.69$ \\
\hline Blue-Brown & 5.73 & 1.41 & $2.97,8.50$ \\
\hline Blue-Green & 4.15 & 1.38 & $1.43,6.87$ \\
\hline Blue-Pink & & & \\
\hline
\end{tabular}

\section{Comparing the 1-minute average noise levels between train lines}

The 1-min $\mathrm{L}_{\text {eq }}$ were compared between train lines using a mixed-effect model, with train ride as the random effect and train line as a fixed effect (Table V). The intra-class correlation is $34.7 \%$, indicating that train ride explains $34.7 \%$ of the variation in the noise levels, after adjusting for the fixed effects. There is only one significant difference in the mean $\mathrm{L}_{\mathrm{eq}}$ levels: between Blue and Pink Line $(\mathrm{p}<.05)$. The $\mathrm{L}_{\mathrm{eq}}$ of the Blue Line is $4 \mathrm{dBA}$ higher than the $\mathrm{L}_{\mathrm{eq}}$ of Pink Line. The differences of $\mathrm{L}_{\mathrm{eq}}$ between the Pink Line and the train lines other than the Blue Line are not 
significant ( $p>.05)$. This result is consistent with the 1-min Leq levels in Table IV. Statistically significant contrasts estimated from the 1 -min $\mathrm{L}_{\mathrm{eq}}$ regression model in the Table $\mathrm{V}$ are shown in Table VI. We can see that the mean of $\mathrm{L}_{\mathrm{eq}}$ of the Blue Line is higher than all the other train lines $(\mathrm{p}<.05)$. None of the $\mathrm{L}_{\mathrm{eq}}$ contrast between other train lines are statistically significantly different.

\section{Calculate and Summarize Noise Levels among Segments of Each Train Lines}

The noise levels are summarized by the location of train segment_-primarily in a tunnel, ground level, or at elevation (Table VII). The mean S.Leq is highest for train segments involving tunnels, $77.23 \mathrm{dBA}$, while the mean of S.Lpeak is highest for train segments primarily at ground level, $110.29 \mathrm{~dB}$.

TABLE VII

SUMMARY OF SEGMENT-NOISE LEVELS BY LOCATION

\begin{tabular}{|l|c|c|}
\hline \multirow{2}{*}{ Segment } & \multicolumn{2}{|c|}{ Mean (SD) Segment Noise Level } \\
\cline { 2 - 3 } & S.Leq (dBA) & S.Lpeak (dB) \\
\hline In Tunnel & $77.23(4.03)$ & $109.47(3.13)$ \\
\hline On Ground & $75.16(3.67)$ & $110.29(2.84)$ \\
\hline Elevated & $73.01(2.82)$ & $108.61(3.40)$ \\
\hline
\end{tabular}




\section{Identify Factors That Influence Noise Levels on Chicago Trains}

To follow up on the summary statistics suggesting that noise level varied with train track location (Table VII), differences were tested using a mixed-effect model with train ride as the random effect and track location as a fixed effect. The overall mean S.Leq at elevated stations is 73.60 dBA (Table VII). The mean S.Leq of train segments involving travel through tunnels is significantly higher than the mean S.Leq of elevated stations $(\mathrm{p}<.05)$. Ground and elevated segments were not significant different, but tunnel segments $1.97 \mathrm{dBA}$ were louder than ground segments (95\% CI: 1.04, 2.89), on average.

Differences in segment-peak noise levels between train track locations were tested using a mixed-effect model with train ride as the random effect (Table VIII). The mean S.Lpeak of train segments primarily at ground level is significantly higher than the mean S.Lpeak of elevated segments (108.80 dB, the intercept). There was no significant difference in peak noise levels between ground and tunnel segments. 
TABLE VIII

LINEAR MIXED-EFFECT MODEL FOR S.LEQ AND S.LPEAK

\begin{tabular}{|c|c|c|c|c|c|c|}
\hline & \multicolumn{3}{|c|}{ S.Leq } & \multicolumn{3}{|c|}{ S.L.Leak } \\
\hline \multicolumn{7}{|c|}{ Quality of the Model Fit: } \\
\hline AIC & \multicolumn{3}{|c|}{2615.84} & \multicolumn{3}{|c|}{2802.92} \\
\hline Log Likelihood & \multicolumn{3}{|c|}{-1302.92} & \multicolumn{3}{|c|}{-1396.46} \\
\hline \multicolumn{7}{|c|}{ Random effects (SD): } \\
\hline Intercept & \multicolumn{3}{|l|}{2.27} & \multicolumn{3}{|l|}{1.69} \\
\hline Residual & \multicolumn{3}{|l|}{2.34} & \multicolumn{3}{|l|}{2.83} \\
\hline \multicolumn{7}{|l|}{ Fixed effects: } \\
\hline & Value & $\mathbf{S E}$ & p-value & Value & $\mathbf{S E}$ & p-value \\
\hline Intercept & 73.60 & 0.45 & 0.00 & 108.80 & 0.36 & 0.00 \\
\hline Ground & 0.17 & 0.41 & 0.68 & 0.91 & 0.47 & 0.05 \\
\hline Tunnel & 2.14 & 0.50 & 0.00 & -0.11 & 0.59 & 0.84 \\
\hline
\end{tabular}

Since the Blue Line has a louder noise level than the other train lines, and tunnels were found to be contributing to the noise level, we considered whether the number of tunnels through which the Blue Line travels explained the high noise level on the Blue Line. This was accomplished using a mixed-effect regression model with train ride as a random effect, train color, and track location (tunnel versus non-tunnel segment). The model results (Table IX) show that both tunnel and Blue Line are independent statistically significant effects $(\mathrm{p}<.05)$. This means that the number of tunnels does not fully explain the noise level on the Blue Line. 


\section{TABLE IX}

LINEAR MIXED-EFFECT MODEL FOR S.LEQ WITH TRAIN RIDE AS A RANDOM EFFECT, TRAIN COLORS AND TRACK LOCATION AS FIXED EFFECTS

\begin{tabular}{|l|l|l|l|}
\hline \multicolumn{3}{|c|}{ Quality of Model Fit: } \\
\hline \multicolumn{3}{|l|}{} & \multicolumn{2}{|c|}{ S.Leq } \\
\hline AIC & 2591.45 \\
\hline Log Likelihood & -1285.72 \\
\hline Random effects (SD): & 1.62 & p-value \\
\hline Intercept & 2.33 & \\
\hline Residual & Value & SE & \\
\hline Fixed effects: & 73.73 & 0.85 & 0.00 \\
\hline & -1.64 & 1.19 & 0.18 \\
\hline Intercept & 0.13 & 1.21 & 0.91 \\
\hline Purple & -0.62 & 1.19 & 0.61 \\
\hline Orange & 4.07 & 1.22 & 0.00 \\
\hline Brown & -0.93 & 1.22 & 0.45 \\
\hline Blue & 1.89 & 0.44 & 0.00 \\
\hline Green & & & \\
\hline Red & & & \\
\hline Tunnel & & \\
\hline
\end{tabular}




\section{E. Comparing Noise Level With Standards}

Table X includes the OSHA Action Level (AL) Dose and ACGIH TLV Dose per ride and 8hour exposure to the noise level of the corresponding rides. The OSHA PEL dose and 8-hour projected dose were not calculated because all of the 1-min $\mathrm{L}_{\mathrm{eq}}$ of all train rides are below the OSHA PEL threshold of $90 \mathrm{dBA}$. In addition, the 1-min average noise levels of the Brown, Red, and Purple Lines are under the OSHA AL and ACGIH TLV threshold of $80 \mathrm{dBA}$; therefore, the doses per ride and per 8 hour of these train lines were not calculated.

The 8-hour projected dose estimates the dose for an 8-hour work shift. It assumes that the single-ride dose remains constant for 8 hours. Since research participants were asked to ride on the first car of the train and sit close to the train drivers, the dose and 8-hour projected dose could be used to estimate the noise exposure of the train drivers. According to OSHA, an employer must implement a hearing conservation program if the employee dose is at or above $50 \%$ of the PEL. As shown in the Table IX, the Blue Line has the highest values of all measures, but none of the exposures exceeds 50\% dose. The highest Blue Line OSHA and TLV 8-hour projected doses are on the O'Hare branch, which are $12.98 \%$ and $25.24 \%$, respectively.

The TWA exposures per ride and per 8-hour period were calculated using equations (3) and (4). The TWA exposures calculated by the ACGIH equation are higher than those calculated by the OSHA equation because the dose used in the ACGIH equation has smaller allowable exposure time than the OSHA equation, and because the exchange rate is $3 \mathrm{dBA}$ for $\mathrm{ACGIH}$ instead of $5 \mathrm{dBA}$ for OSHA. The highest OSHA AL and TLV 8h-TWA exposures are on the O'Hare branch of the Blue Line, $75 \mathrm{dBA}$ and $79 \mathrm{dBA}$ respectively. In addition, the OSHA and TLV TWA exposure per ride and per 8-hour exposure period on the O'Hare branch are higher than the TWA values on the Forest Park branch. Some of the OSHA AL TWA exposures per ride could not be calculated but the dosimeter software provided an estimate. Estimated doses are marked with two stars in Table X. 
TABLE X

COMPARISON WITH OSHA AND NIOSH NOISE STANDARDS

\begin{tabular}{|c|c|c|c|c|c|c|c|c|c|}
\hline \multirow[b]{3}{*}{ Line } & \multirow[b]{3}{*}{ Branch } & \multicolumn{4}{|c|}{ Calculated OSHA Action Level } & \multicolumn{4}{|c|}{ Calculated TLV } \\
\hline & & \multicolumn{2}{|c|}{ Per ride } & \multicolumn{2}{|c|}{ Per 8 hours } & \multicolumn{2}{|c|}{ Per ride } & \multicolumn{2}{|c|}{ Per 8 hours } \\
\hline & & $\begin{array}{l}\text { TWA } \\
\text { (dBA) }\end{array}$ & $\begin{array}{c}\text { Dose } \\
(\%)\end{array}$ & $\begin{array}{l}\text { TWA } \\
\text { (dBA) }\end{array}$ & $\begin{array}{c}\text { Dose } \\
(\%)\end{array}$ & $\begin{array}{c}\text { TWA } \\
\text { (dBA) }\end{array}$ & $\begin{array}{c}\text { Dose } \\
(\%)\end{array}$ & $\begin{array}{l}\text { TWA } \\
\text { (dBA) }\end{array}$ & $\begin{array}{r}\text { Dose } \\
(\%)\end{array}$ \\
\hline Blue & Downtown-Forest Ride 1 & 54.8 & 0.76 & 74.08 & 11.01 & 66.39 & 1.38 & 78 & 19.94 \\
\hline Blue & Downtown-Forest Ride 2 & 52.6 & 0.56 & 72.62 & 8.99 & 64.44 & 0.88 & 76.5 & 14.13 \\
\hline Blue & Downtown-O'Hare Ride 1 & 55.86 & 0.88 & 73.26 & 9.82 & 66.67 & 1.47 & 77.14 & 16.39 \\
\hline Blue & Downtown-O'Hare Ride 2 & 59.25 & 1.41 & 75.27 & 12.98 & 69.36 & 2.73 & 79.02 & 25.24 \\
\hline Brown & Downtown-Kimball Ride 1 & $27.3 * *$ & $*$ & $*$ & $0.2 * *$ & $*$ & $*$ & $*$ & $*$ \\
\hline Brown & Downtown-Kimball Ride 2 & $20.2 * *$ & $*$ & $*$ & $0.1 * *$ & $*$ & $*$ & $*$ & $*$ \\
\hline Brown & Downtown-Kimball Ride 3 & $43.4 * *$ & $*$ & $*$ & $1.6^{* *}$ & $*$ & $*$ & $*$ & $*$ \\
\hline Brown & Downtown-Kimball Ride 4 & $44.4 * *$ & $*$ & $*$ & $1.5^{* *}$ & $*$ & $*$ & $*$ & $*$ \\
\hline Green & Downtown-Ashland & $11.2^{* *}$ & $*$ & $*$ & $0.0^{* *}$ & $*$ & $*$ & $*$ & $*$ \\
\hline Green & Downtown-Cottage Grove & $36.7 * *$ & $*$ & $*$ & $1.5^{* *}$ & $*$ & $*$ & $*$ & $*$ \\
\hline
\end{tabular}


COMPARISON WITH OSHA AND NIOSH NOISE STANDARDS

\begin{tabular}{|c|c|c|c|c|c|c|c|c|c|}
\hline \multirow[b]{3}{*}{ Line } & \multirow[b]{3}{*}{ Branch } & \multicolumn{4}{|c|}{ Calculated OSHA Action Level } & \multicolumn{4}{|c|}{ Calculated TLV } \\
\hline & & \multicolumn{2}{|c|}{ Per ride } & \multicolumn{2}{|c|}{ Per 8 hours } & \multicolumn{2}{|c|}{ Per ride } & \multicolumn{2}{|c|}{ Per 8 hours } \\
\hline & & $\begin{array}{l}\text { TWA } \\
(\mathbf{d B A})\end{array}$ & $\begin{array}{c}\text { Dose } \\
(\%)\end{array}$ & $\begin{array}{c}\text { TWA } \\
(\text { dBA })\end{array}$ & $\begin{array}{c}\text { Dose } \\
(\%)\end{array}$ & $\begin{array}{c}\text { TWA } \\
(\text { dBA })\end{array}$ & $\begin{array}{c}\text { Dose } \\
(\%)\end{array}$ & $\begin{array}{c}\text { TWA } \\
(\mathbf{d B A})\end{array}$ & $\begin{array}{c}\text { Dose } \\
(\%)\end{array}$ \\
\hline Green & Downtown-Harlem Ride 1 & $39.3 * *$ & $*$ & $*$ & $1.2 * *$ & $*$ & $*$ & $*$ & $*$ \\
\hline Green & Downtown-Harlem Ride 2 & 47.33 & 0.27 & 66.97 & 4.11 & 61.23 & 0.42 & 72.97 & 6.27 \\
\hline Orange & Downtown-Midway Ride 1 & 36.5 & 0.06 & 54.61 & 0.74 & 54.03 & 0.08 & 64.95 & 0.99 \\
\hline Orange & Downtown-Midway Ride 2 & 35.2 & 0.05 & 53.89 & 0.67 & 53.45 & 0.07 & 64.44 & 0.88 \\
\hline Orange & Downtown-Midway Ride 3 & $29.7 * *$ & $*$ & $*$ & $0.3 * *$ & $*$ & $*$ & $*$ & $*$ \\
\hline Orange & Downtown-Midway Ride 4 & $27.7 * *$ & $*$ & $*$ & $0.2 * *$ & $*$ & $*$ & $*$ & $*$ \\
\hline Pink & Downtown-Cermark Ride 1 & 48.33 & 0.31 & 66.56 & 3.88 & 62.24 & 0.53 & 73.22 & 6.65 \\
\hline Pink & Downtown-Cermak Ride 2 & 47.6 & 0.28 & 65.79 & 3.49 & 61.33 & 0.43 & 72.30 & 5.38 \\
\hline Pink & Downtown-Cermak Ride 3 & 36.5 & 0.06 & 54.7 & 0.75 & 54.03 & 0.08 & 65.17 & 1.04 \\
\hline Pink & Downtown-Cermak Ride 4 & $34.1 * *$ & $*$ & $*$ & $0.4 * *$ & $*$ & $*$ & $*$ & $*$ \\
\hline Purple & Downtown-Linden Ride 1 & $25.2 * *$ & $*$ & $*$ & $0.1 * *$ & $*$ & $*$ & $*$ & $*$ \\
\hline
\end{tabular}


COMPARISON WITH OSHA AND NIOSH NOISE STANDARDS

\begin{tabular}{|c|c|c|c|c|c|c|c|c|c|}
\hline \multirow[b]{3}{*}{ Line } & \multirow[b]{3}{*}{ Branch } & \multicolumn{4}{|c|}{ Calculated OSHA Action Level } & \multicolumn{4}{|c|}{ Calculated TLV } \\
\hline & & \multicolumn{2}{|c|}{ Per ride } & \multicolumn{2}{|c|}{ Per 8 hours } & \multicolumn{2}{|c|}{ Per ride } & \multicolumn{2}{|c|}{ Per 8 hours } \\
\hline & & $\begin{array}{l}\text { TWA } \\
(\mathrm{dBA})\end{array}$ & $\begin{array}{c}\text { Dose } \\
(\%)\end{array}$ & $\begin{array}{c}\text { TWA } \\
(\mathbf{d B A})\end{array}$ & $\begin{array}{c}\text { Dose } \\
(\%)\end{array}$ & $\begin{array}{c}\text { TWA } \\
(\text { dBA })\end{array}$ & $\begin{array}{l}\text { Dose } \\
(\%)\end{array}$ & $\begin{array}{c}\text { TWA } \\
(\mathbf{d B A})\end{array}$ & $\begin{array}{r}\text { Dose } \\
(\%)\end{array}$ \\
\hline Purple & Downtown-Linden Ride 2 & $30.3 * *$ & $*$ & $*$ & $0.2 * *$ & $*$ & $*$ & $*$ & $*$ \\
\hline Purple & Downtown-Linden Ride 3 & $39.6 * *$ & $*$ & $*$ & $0.6 * *$ & $*$ & $*$ & $*$ & $*$ \\
\hline Purple & Downtown-Linden Ride 4 & $50.7 * *$ & $*$ & $*$ & $3.3 * *$ & $*$ & $*$ & $*$ & $*$ \\
\hline Red & Downtown-Howard Ride 1 & $33.4 * *$ & $*$ & $*$ & $0.5 * *$ & $*$ & $*$ & $*$ & $*$ \\
\hline Red & Downtown-Howard Ride 2 & $41.3 * *$ & $*$ & $*$ & $1.3 * *$ & $*$ & $*$ & $*$ & $*$ \\
\hline Red & Downtown-95th Ride 1 & $36.0 * *$ & $*$ & $*$ & $0.8 * *$ & $*$ & $*$ & $*$ & $*$ \\
\hline Red & Downtown-95th Ride 2 & $41.5 * *$ & $*$ & $*$ & $1.9 * *$ & $*$ & $*$ & $*$ & $*$ \\
\hline
\end{tabular}

*: Not applicable because the noise level is below the OSHA Action Level and TLV threshold of $80 \mathrm{dBA}$.

**: Casella software calculations. 


\section{DISCUSSION}

Patterns of the segment noise levels were consistent with patterns of the 1-min noise levels. The 1-min average (Leq) and segment-average noise levels (S.Leq) on the Blue Line were significantly higher than other train lines $(\mathrm{p}<.05)$. The mean $\mathrm{L}_{\mathrm{eq}}$ between the two branches of the Blue line were not significantly different from each other. This similarity between branches was also observed for the Green and Red Lines. The Purple Line had the lowest average noise level (71.23 $\mathrm{dBA}$ ). Both the Red and Blue lines run underground through the Loop (on different tracks), but the mean $\mathrm{L}_{\mathrm{eq}}$ level of the Blue Line was $5.7 \mathrm{dBA}$ higher than the Red Line $(\mathrm{p}<.05)$. We have provided evidence that some factors including tunnel and variation among train lines can contribute to the differences in noise levels. Some factors not considered in this study, such as wheel, brake conditions, and the quality of the track, may explain some differences among train lines.

In the Neitzel et al. study on New York City’s Mass Transit System, the mean Leq measured inside the MTA and PATH trains was $79.3 \mathrm{dBA}$ and $79.2 \mathrm{dBA}$, which are a little higher than the mean $\mathrm{L}_{\text {eq }}$ of the Blue Line. The mean $\mathrm{L}_{\text {eq }}$ measured in the BART study was about $4 \mathrm{dBA}$ higher than the mean $L_{e q}$ on the Blue Line (Dinno et al., 2011).

There were three measured $\mathrm{L}_{\text {peak }}$ values that exceeded $120 \mathrm{~dB}$, which is the threshold for hearing impairment in children used by WHO (WHO 1999). The maximum of $\mathrm{L}_{\text {peak }}$ value was on the Blue Line, $127 \mathrm{~dB}$, which does not exceed the recommendation of impulsive noise exposure of 140 dB by OSHA (OSHA 2015). This maximum $\mathrm{L}_{\text {peak }}$ on the CTA was lower than the maximum $\mathrm{L}_{\text {peak }}$ recorded in the BART study $(147 \mathrm{~dB})$, and $\mathrm{L}_{\text {peak }}$ values above $120 \mathrm{~dB}$ were recorded less frequently in Chicago than in the BART study (Dinno et al., 2011). 
In the noise study conducted in New York City by Neitzel et al. (2009), they measured noise level at the vehicle boarding platform to capture noise level of vehicles passing a station and found platform noise levels to be significantly higher than the combined noise measurement across stations. Therefore, I proposed a hypothesis that the number of passing trains is associated with the noise level within the monitored train ride. However, the scatter plot (Figure 4) showed no association between passing trains and noise levels.

Noise level varied with train track locations. The mean of S.Leq of train segments involving travel through tunnel, $76.96 \mathrm{dBA}$, was significantly higher than the mean S.Leq of elevated segments and ground segments, which were 73.85 and $74.81 \mathrm{dBA}$ respectively $(\mathrm{p}<.05)$. The mean $\mathrm{S} . \mathrm{L}_{\mathrm{peak}}$ of train segments on the ground level was significantly higher than the mean S.Lpeak of elevated segments, but the difference of the mean S.Lpeak between ground segments and tunnel segments was not statistically significant ( $p>.05$ ). Elevated $\mathrm{L}_{\mathrm{eq}}$ level observed in tunnels is consistent with the study in New York (Neitzel et al., 2009) and in the BART study (Dinno et al., 2011). Dinno et al. found that the Leq increased by $5.1 \mathrm{dBA}$ in segments involving travel through the tunnels (Dinno et al., 2011).

The Blue Line has the highest single-ride dose and 8-h projected dose, but the single-ride and 8-hour projected doses of all train lines did not exceed the OSHA AL or ACGIH TLV standards. The OSHA requires employers to implement a hearing conversation program if employees are exposed above $50 \%$ of the noise dose. The TLV 8-hour TWA is highest on the O'Hare branch of the Blue Line, $79 \mathrm{dBA}$, and this value does not exceed the TLV occupational exposure limit of $85 \mathrm{dBA}$. However, train drivers may have a unique exposure because they have longer exposure durations than riders and are in a separate cab from riders. In particular, the driver cab has openable windows; and opening the windows could increase noise exposure for the train operator. Therefore, the noise exposure on the Blue Line may pose potential health risks to train drivers. The TWA 8-hour levels 
on the Blue Line calculated by the ACGIH TLV equation are similar with the mean 8-hour noise exposure of bus drivers in Curitiba City Brazil, which are from 74 dBA to 79 dBA (Bruno et al., 2013).

The study in New York found the Leq noise level on the underground platform was significantly higher than the $\mathrm{L}_{\text {eq }}$ measured inside train car (Neitzel et al., 2009). We did not examine the noise levels on the platform at CTA stations but it can be anticipated that the noise levels on CTA platforms are probably higher than the noise levels measured in the train car because of the shielding offered by the train car to riders. Since decibels are logarithms, therefore, a small increase in noise level cause the risk of hearing loss more intense.

The doses per ride on CTA train lines are relatively small and do not exceed OSHA AL and TLV standards, which means noise levels on CTA trains are not likely to pose noise-related health risks to train riders. Diaz et al. (2005) found that the noise exposure during transportation accounts for $12.6 \%$ of the total daily noise exposure perceived by an inhabitant of the Madrid region in Spain, where the mean $\mathrm{L}_{\mathrm{eq}}$ on subway was about $79 \mathrm{dBA}$, which is similar with the average noise levels on the Blue Line.

Dinno et al. (2011) found the Leq increased linearly, with average velocity by $0.52 \mathrm{dBA} \mathrm{km}^{-1}$ $\mathrm{h}^{-1}$. We were not able to obtain GIS data of CTA train lines or information about segment length from CTA; therefore, average velocity could not be constructed using segment lengths. This is an area for future work.

In addition, we had a small sample size of 28 train rides and could not measure the noise levels on all train tracks. For example, we could only measure the noise levels of the Purple, Orange, Pink, and Brown Lines one way, on the track departing from downtown. We hope that we can expand this study to measure noise levels on the other tracks departing from Linden, Midway 
International Airport, 54th/Cermak, and Kimball to downtown. From there, we can compare the noise levels on different tracks of the same train line. 


\section{CONCLUSION}

Our results indicate that noise exposure on CTA train lines is not high enough to pose significant health risks for train riders. The noise doses per 8 hours and 8-hour TWA were calculated on each train line to estimate occupational noise exposure of train drivers. Although these values do not exceed the OSHA and TLV standards, train drivers may have unique exposures because they are in separate cab from riders and have longer exposure durations than riders. We noted significant differences between the mean noise levels on some train lines. The mean average noise level on the Blue Line is significantly higher than the other train lines. In addition, the mean 1-min average noise level of train segments involving travel through tunnels was significantly higher than that of ground and elevated segments. Public health authorities can recommend CTA to put notification on the Blue Line to warn riders about possible high noise exposure in the tunnel.

In order to capture the occupational exposure of train drivers, future studies should focus on asking train drivers to wear a noise dosimeter during their work shift. If their noise exposure exceeds the TLV of $85 \mathrm{dBA}$, hearing protection should be required for CTA train drivers. The highest 8-h TWA noise exposure inside the train is $79 \mathrm{dBA}$; therefore, the noise level outside could be much louder than that. Therefore, research in the future should take into account of noise exposure in the environment as well. 


\section{REFERENCES}

American Industrial Hygiene Association. The Noise Manual. 5th edition. Edited by E. H. Berger et al. Fairfax, VA: American Industrial Hygiene Association Press, 2003.

Acoustic Glossary. "Noise Dose: Definitions, Terms, Units and Measurement." Accessed April 4, 2015. http://www.acoustic-glossary.co.uk/noise-dose.htm.

Babisch, W., H. Ising, J. E. Gallacher, P. M. Sweetnam, and P. C. Elwood. "Traffic Noise And Cardiovascular Risk: The Caerphilly and Speedwell Studies, Third Phase 10-year Follow Up." Archives of Environmental Health 54, no. 3 (1999): 210-6.

Banerjee, D., P. P. Das, and A. Foujdar. "Association between Road Traffic Noise and Prevalence of Coronary Heart Disease.” Environmental Monitoring and Assessment 186, no. 5 (2013): 2885-93.

Bruno, P. S., Q. R. Marcos, C. Amanda, and Z. H. Paulo. "Annoyance Evaluation and the Effect of Noise On The Health Of Bus Drivers." Noise \& Health 15, no. 66 (2013): 301-6.

Canadian Centre for Occupational Health and Safety. "Noise Basic Information." Accessed April 30, 2015. http://www.ccohs.ca/oshanswers/phys_agents/noise_basic.html.

Chicago Transit Authority. "Chicago Transit Authority Facts at A Glance.” Accessed January 15, 2015. http://www.transitchicago.com/about/facts.aspx.

Diaz, César, and A. Pedrero. "Sound Exposure During Daily Activities.” Applied Acoustics 67, no. 3 (2006): 271-283. 
Dinno, A., C. Powell, and M. M. King. “A Study of Riders' Noise Exposure on Bay Area Rapid Transit Trains." Journal of Urban Health: Bulletin of the New York Academy of Medicine 88, no. 1 (2011): 1-13.

Elmenhorst, E. M., J. Quehl, U. Muller, and M. Basner. "Nocturnal Air, Road, and Rail Traffic Noise and Daytime Cognitive Performance and Annoyance." The Journal of the Acoustical Society of America 135, no. 1 (2014): 213-22.

Kirchner, B. D, E. C. Evenson, R. A. Dobie, P. Rabinowitz, J. Crawford, R. Kopke, and W. T. Hudson. “Occupational Noise-Induced Hearing Loss.” American College of Occupational and Environmental Medicine 54, no. 1(2012): 106-108.

Lie, A., M. Skogstad, T. S. Johnsen, B. Engdahl, and K. Tambs. "Hearing Status among Norwegian Train Drivers and Train Conductors." Occupational Medicine (Oxford, England) 63, no. 8 (2013): 544-8.

Malleson, S. M. "Confirmation of Noise Exposure Levels by Analysis of the Audiometric Data in Long Service Underground Train Drivers." The Journal of the Society of Occupational Medicine 39, no. 3 (1989): 107-10.

Masterson, E.A., S. Tak, C. L. Themann, D. K. Wall, M. R. Groenewold, J. A. Deddens, and G. M. Calvert. "Prevalence of Hearing Loss in the United States by Industry." The American Journal of Industrial Medicine 56, no. 6 (2013): 670-681.

Neitzel, R., R. Gershon, M. Zeltser, A. Canton, and M. Akram. "Noise Levels Associated with New York City's Mass Transit System.” Am J Public Health 99, no. 8 (2009): 1393-1399. 
Nelson, D. I., R. Y. Nelson, M. Concha-Barrientos, and M. Fingerhut. "The Global Burden of Occupational Noise-Induced Hearing Loss.” American Journal of Industrial Medicine 48, no. 6 (2005): 446-58.

National Institute for Occupational Safety and Health. "Noise and Hearing Loss Prevention." Accessed Jan 20, 2015. http://www.cdc.gov/niosh/topics/noise/stats.html.

National Institute for Occupational Safety and Health. "Criteria for a Recommended Standard: Occupational Noise Exposure.” Revised criteria. DHHS/NIOSH Pub No 98-126. Cincinnati, OH: Department of Health and Human Services, 1998.

Occupational Safety and Health Administration. "OSHA Technical Manual (OTM) Section III: Chapter 5.” Accessed March 20, 2015. https://www.osha.gov/dts/osta/otm/new_noise/.

Occupational Safety and Health Administration. "Occupational Safety and Health Standards: Occupational Noise Exposure.” Assessed April 1, 2015. https://www.osha.gov/pls/oshaweb/owadisp.show_document?p_table=standards\&p_id=9735.

Palmer, K. T., M. J. Griffin, H. E. Syddall, A. Davis, B. Pannett, and D. Coggon. “Occupational Exposure to Noise and the Attributable Burden of Hearing Difficulties in Great Britain." Occupational and Environmental Medicine 59, no. 9 (2002): 634-9.

Sorensen, M., M. Ketzel, K. Overvad, A. Tjonneland, and O. Raaschou-Nielsen. "Exposure to Road Traffic and Railway Noise and Postmenopausal Breast Cancer: A Cohort Study.” International Journal of Cancer Journal International Du Cancer 134, no. 11 (2014): 2691-8.

Trombetta Zannin, P. H., and F. Bunn. "Noise Annoyance Through Railway Traffic-A Case Study." Journal of Environmental Health Science \& Engineering 12, no. 1(2014): $12-4$. 
World Health Organization. “Guidelines for Community Noise.” Accessed Jan 10, 2015. http://whqlibdoc.who.int/hq/1999/a68672.pdf.

World Health Organization. "Occupational Noise, Assessing the Burden of Disease from WorkRelated Hearing Impairment at National and Local Levels.” Accessed Jan 10, 2015. http://www.who.int/quantifying_ehimpacts/publications/en/ebd9.pdf. 
APPENDICES 


\section{APPENDIX A \\ COMPARING THE SEGMENT-PEAK NOISE LEVEL (S.LPEAK) AND SEGMENT- AVERAGE NOISE LEVELS (LEQ) BETWEEN TRAIN LINES}

The segment-peak noise levels (S.Leak) were compared between train lines using mixedeffect model, with the random effect is train ride (Table XI). The intra-class correlation is $24 \%$, indicating that train ride explains $24 \%$ of the variation in noise levels, after adjusting for the fixed effects. As shown in Table XII, S.Lpeak levels of Blue Line and Brown Line are statistically higher than the intercept, which is the mean S.L $L_{\text {peak }}$ level on the Pink Line, $108.11 \mathrm{~dB}$.

The pattern of statistically significant contrasts was similar for $\mathrm{S}$. $\mathrm{L}_{\text {peak }}$ and $\mathrm{L}_{\text {peak }}$ (Table V).

Specifically, S.Leak levels of Blue and Brown Line are significantly higher than S.Lpeak of the Pink Line ( $\mathrm{p}<.05)$. In addition, S. $\mathrm{L}_{\text {peak }}$ of the Blue Line is also significantly higher than S.L $\mathrm{L}_{\text {peak }}$ of the Purple Line, and the difference is $2.49 \mathrm{~dB}$. 


\section{APPENDIX A (continued)}

\section{TABLE XI}

LINEAR MIXED-EFFECT MODEL FOR SEGMENT-PEAK NOISE LEVELS

\begin{tabular}{|c|c|c|c|}
\hline & \multicolumn{3}{|c|}{ S.Lpeak } \\
\hline \multicolumn{4}{|c|}{ Quality of Model Fit: } \\
\hline AIC & \multicolumn{3}{|l|}{2795.92} \\
\hline Log Likelihood & \multicolumn{3}{|c|}{-1388.96} \\
\hline \multicolumn{4}{|c|}{ Random effects (SD): } \\
\hline Intercept & \multicolumn{3}{|l|}{1.59} \\
\hline Residual & \multicolumn{3}{|l|}{2.83} \\
\hline \multicolumn{4}{|l|}{ Fixed effects: } \\
\hline & \begin{tabular}{|l} 
Value \\
\end{tabular} & SE & p-value \\
\hline Intercept & 107.27 & 0.85 & 0.00 \\
\hline Purple & 0.56 & 1.20 & 0.65 \\
\hline Orange & 1.49 & 1.22 & 0.23 \\
\hline Brown & 2.61 & 1.20 & 0.04 \\
\hline Blue & 3.19 & 1.22 & 0.02 \\
\hline Green & 2.12 & 1.24 & 0.10 \\
\hline Red & 1.73 & 1.22 & 0.17 \\
\hline
\end{tabular}




\title{
APPENDIX A (continued)
}

\author{
TABLE XII
}

SIGNIFICANT S. LPEAK CONTRASTS BETWEEN TRAIN LINES, WITH SE ESTIMATES FOR THE DIFFERENCE AND 95\% CIs

\begin{tabular}{|l|l|l|l|}
\hline Train Lines Compared & Contrast & SE & 95\% CI \\
\hline Blue-Purple & 2.63 & 1.22 & $0.23,5.02$ \\
\hline Blue-Pink & 3.19 & 1.22 & $0.78,5.59$ \\
\hline Brown-Pink & 2.61 & 1.20 & $0.26,4.97$ \\
\hline
\end{tabular}

The segment-average noise levels $\left(\mathrm{S}\right.$. $\left.\mathrm{L}_{\mathrm{eq}}\right)$ were compared between train lines using a mixedeffect model, with train ride is the random effect and train line as the fixed effect (Table XIII). The intra-class correlation is $32.1 \%$, indicating that train ride explains $32.1 \%$ of the variation in noise levels, after adjusting for train line. Consistent with the mixed effect model of 1-min Leq (Table V), only the S.Leq level of the Blue Line differs significantly from the intercept, which is the mean S.Leq on the Pink Line, $73.73 \mathrm{dBA}$. Additionally statistically significant contrasts are shown in Table XIV. 


\section{APPENDIX A (continued)}

\section{TABLE XIII}

LINEAR MIXED-EFFECT MODEL FOR SEGMENT-AVERAGE NOISE LEVEL

\begin{tabular}{|c|c|c|c|}
\hline \multicolumn{4}{|c|}{ Quality of Model Fit: } \\
\hline AIC & \multicolumn{3}{|c|}{2607.66} \\
\hline Log Likelihood & \multicolumn{3}{|c|}{-1294.83} \\
\hline \multicolumn{4}{|c|}{ Random effects (SD): } \\
\hline Intercept & \multicolumn{3}{|l|}{1.63} \\
\hline Residual & \multicolumn{3}{|l|}{2.37} \\
\hline \multicolumn{4}{|l|}{ Fixed effects: } \\
\hline & Value & SE & p-value \\
\hline Intercept & 73.73 & 0.85 & 0.00 \\
\hline Purple & -1.64 & 1.20 & 0.19 \\
\hline Orange & 0.13 & 1.21 & 0.91 \\
\hline Brown & -0.62 & 1.20 & 0.61 \\
\hline Blue & 4.77 & 1.22 & $\mathbf{0 . 0 0}$ \\
\hline Green & -0.94 & 1.23 & 0.45 \\
\hline Red & -0.94 & 1.21 & 0.45 \\
\hline
\end{tabular}




\section{APPENDIX A (continued)}

\section{TABLE XIV}

SIGNIFICANT S.LEQ CONTRAST BETWEEN TRAIN LINES, WITH SE ESTIMATES FOR THE DIFFERENCE AND 95\% CI

\begin{tabular}{|l|l|l|l|}
\hline Train Lines Compared & Contrast & SE & CI \\
\hline Blue-Red & 5.71 & 1.23 & $3.30,8.12$ \\
\hline Blue-Purple & 6.42 & 1.21 & $4.03,8.80$ \\
\hline Blue-Orange & 4.64 & 1.22 & $2.23,7.05$ \\
\hline Blue-Brown & 5.40 & 1.21 & $3.01,7.78$ \\
\hline Blue-Green & 5.71 & 1.24 & $3.27,8.12$ \\
\hline Blue-Pink & & & \\
\hline
\end{tabular}




\section{APPENDIX B}

\section{Observation Instruction}

\section{A. Blue Line Observation Instruction \\ 1. Occupancy categorization}

Please observe the number of riders on the car when leaving the station. Circle one of

the categories:

- LOW: Many open seats on the car, though a few riders may be standing.

- MEDIUM: Most of the seats are full and some riders are standing.

- HIGH: Most of the seats are full and many riders are standing (crowded).

\section{Time}

Please record the time indicated on the digital clock when doors are opened at each

station. The time will be recorded to the minute, such as 9:31.

\section{Passing train observation}

Please record the time when another train passes by. The time will be recorded to the minute, such as 9:31.

\section{Surrounding environment}

Record the time when the train changes from being ELEVATED into TUNNEL between UIC-HALSTED and CLINTON.

Record the time when the train changes from TUNNEL to being ELEVATED between DIVISION and DAMEN. 


\section{APPENDIX B (continued)}

Record the time when the train changes from being ELEVATED into TUNNEL between CALIFORNIA and LOGAN SQUARE.

Record the time when the train changes from TUNNEL to GROUND between

BELMONT and ADDISON.

Record the time when the train changes from GROUND to TUNNEL between ROSEMONT and O'HARE.

\section{Unusual circumstances}

Please record unusual circumstances that could increase the noise level on the train. For example, note if people are talking loudly or playing music.

\section{6. $\quad$ Train car model}

Please note if the train car has center-facing seats (write "center"). 
APPENDIX B (continued)

\section{Direction: Blue line from Forest Park to O'Hare}

Train car model:

Date:

\begin{tabular}{|c|c|c|c|c|c|}
\hline Station & Time & Occupancy & $\begin{array}{l}\text { Passing train } \\
\text { observation } \\
\text { (Time) }\end{array}$ & $\begin{array}{c}\text { Surrounding } \\
\text { environment } \\
\text { (Time) }\end{array}$ & $\begin{array}{l}\text { Unusual } \\
\text { circumstances }\end{array}$ \\
\hline Forest Pa & & & & & \\
\hline Harlem & & & & & \\
\hline Oak Park & & & & & \\
\hline Austin & & & & & \\
\hline Cicero & & & & & \\
\hline Pulaski & & & & & \\
\hline $\begin{array}{l}\text { Kedzie- } \\
\text { Homan }\end{array}$ & & & & & \\
\hline Western & & & & & \\
\hline
\end{tabular}


APPENDIX B (continued)

\begin{tabular}{|c|c|c|c|c|c|}
\hline Station & Time & Occupancy & $\begin{array}{l}\text { Passing train } \\
\text { observation } \\
\text { (Time) }\end{array}$ & $\begin{array}{c}\text { Surrounding } \\
\text { environment } \\
\text { (Time) }\end{array}$ & $\begin{array}{l}\text { Unusual } \\
\text { circumstances }\end{array}$ \\
\hline $\begin{array}{l}\text { Illinois } \\
\text { Medical } \\
\text { District }\end{array}$ & & & & & \\
\hline Racine & & & & & \\
\hline UIC-Hals & & & & & \\
\hline Clinton & & & & & \\
\hline La Salle & & & & & \\
\hline Jackson & & & & & \\
\hline Monroe & & & & & \\
\hline Washingt & & & & & \\
\hline Clark/Lal & & & & & \\
\hline Grand & & & & & \\
\hline Chicago & & & & & \\
\hline
\end{tabular}


APPENDIX B (continued)

\begin{tabular}{|c|c|c|c|c|c|}
\hline Station & Time & Occupancy & $\begin{array}{c}\text { Passing train } \\
\text { observation } \\
\text { (Time) }\end{array}$ & $\begin{array}{c}\text { Surrounding } \\
\text { environment } \\
\text { (Time) }\end{array}$ & $\begin{array}{l}\text { Unusual } \\
\text { circumstances }\end{array}$ \\
\hline Division & & & & & \\
\hline Damen & & & & & \\
\hline Western & & & & & \\
\hline California & & & & & \\
\hline $\begin{array}{l}\text { Logan } \\
\text { Square }\end{array}$ & & & & & \\
\hline Belmont & & & & & \\
\hline Addison & & & & & \\
\hline Irving Park & & & & & \\
\hline Montrose & & & & & \\
\hline $\begin{array}{l}\text { Jefferson } \\
\text { Park }\end{array}$ & & & & & \\
\hline Harlem & & & & & \\
\hline Cumberland & & & & & \\
\hline
\end{tabular}


APPENDIX B (continued)

\begin{tabular}{|c|c|c|c|c|c|}
\hline Station & Time & Occupancy & $\begin{array}{c}\text { Passing train } \\
\text { observation } \\
\text { (Time) }\end{array}$ & $\begin{array}{c}\text { Surrounding } \\
\text { environment } \\
\text { (Time) }\end{array}$ & $\begin{array}{l}\text { Unusual } \\
\text { circumstances }\end{array}$ \\
\hline Rosemor & & & & & \\
\hline O'Hare & & & & & \\
\hline
\end{tabular}




\section{APPENDIX B (continued)}

\section{B. Brown Line Observation Instruction}

\section{Occupancy categorization}

Please observe the number of riders on the car when leaving the station. Circle one of the categories:

- LOW: Many open seats on the car, though a few riders may be standing.

- MEDIUM: Most of the seats are full and some riders are standing.

- HIGH: Most of the seats are full and many riders are standing (crowded).

\section{Time}

Please record the time indicated on the digital clock when doors are opened at each station. The time will be recorded to the minute, such as 9:31.

\section{3. $\quad$ Passing train observation}

Please record the time when another train passes by. The time will be recorded to the minute, such as 9:31.

\section{Surrounding environment}

Recording the time when the train change from being elevated to on ground between

\section{Rockwell and Francisco.}

\section{Unusual circumstances}

Please record unusual circumstances that could increase the noise level on the train. For example, note if people are talking loudly or playing music.

\section{6. $\quad$ Train car model}

Please note if the train car has center-facing seats (write "center"). 
APPENDIX B (continued)

Direction: Pink line to 54th/ Cermak

Train car model:

Date:

\begin{tabular}{|c|c|c|c|c|c|}
\hline Station & Time & Occupancy & $\begin{array}{c}\text { Passing train } \\
\text { observation } \\
\text { (Time) }\end{array}$ & $\begin{array}{c}\text { Surrounding } \\
\text { environment } \\
\text { (Time) }\end{array}$ & $\begin{array}{l}\text { Unusual } \\
\text { circumstances }\end{array}$ \\
\hline Washington/I & & & & & \\
\hline Quincy & & & & & \\
\hline $\begin{array}{l}\text { LaSalle/ Van } \\
\text { Buren }\end{array}$ & & & & & \\
\hline $\begin{array}{l}\text { Harold } \\
\text { Washington } \\
\text { Library }\end{array}$ & & & & & \\
\hline Adams/Waba & & & & & \\
\hline Madison/Wat & & & & & \\
\hline Randolph/Wa & & & & & \\
\hline State/Lake & & & & & \\
\hline Clark/Lake & & & & & \\
\hline $\begin{array}{l}\text { Merchandise } \\
\text { Mart }\end{array}$ & & & & & \\
\hline
\end{tabular}


APPENDIX B (continued)

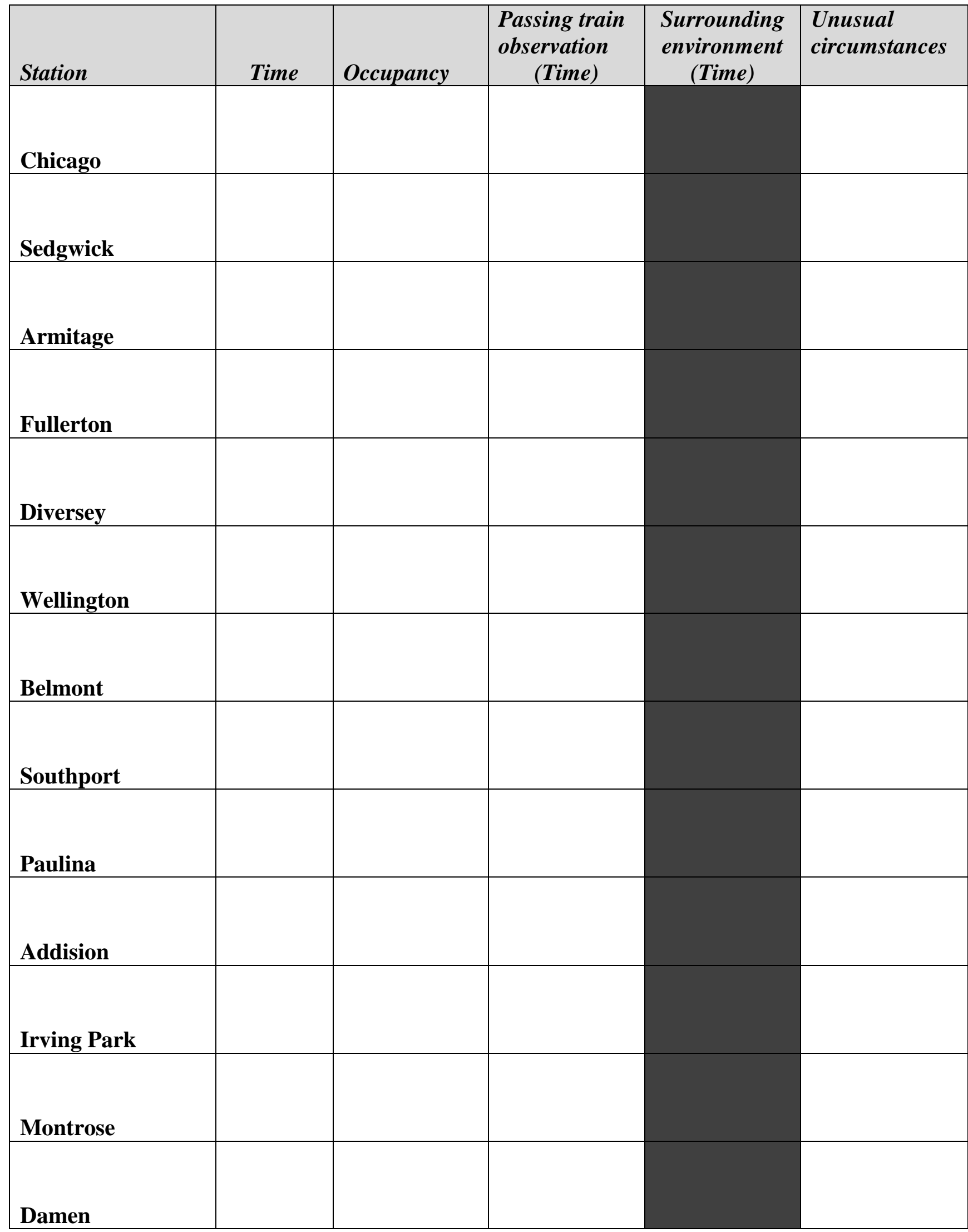


APPENDIX B (continued)

\begin{tabular}{|l|l|l|l|l|l|}
\hline Station & Time & Occupancy & $\begin{array}{l}\text { Passing train } \\
\text { observation } \\
\text { (Time) }\end{array}$ & $\begin{array}{l}\text { Surrounding } \\
\text { environment } \\
\text { (Time) }\end{array}$ & $\begin{array}{l}\text { Unusual } \\
\text { circumstances }\end{array}$ \\
\hline Western & & & & & \\
Rockwell & & & & & \\
\hline Francisco & & & & & \\
\hline Kedzie & & & & & \\
\hline & & & & & \\
\hline
\end{tabular}




\section{APPENDIX B (continued)}

\section{Green Line Observation Instruction}

\section{Occupancy categorization}

Please observe the number of riders on the car when leaving the station. Circle one of the categories:

- LOW: Many open seats on the car, though a few riders may be standing.

- MEDIUM: Most of the seats are full and some riders are standing.

- HIGH: Most of the seats are full and many riders are standing (crowded).

\section{Time}

Please record the time indicated on the digital clock when doors are opened at each station. The time will be recorded to the minute, such as 9:31.

\section{Passing train observation}

Please record the time when another train passes by. The time will be recorded to the minute, such as 9:31.

\section{Unusual circumstances}

Please record unusual circumstances that could increase the noise level on the train. For example, note if people are talking loudly or playing music.

\section{Train car model}

Please note if the train car has center-facing seats (write "center"). 
APPENDIX B (continued)

\section{Direction: Harlem/Lake to Oak Park}

Train car model:

Date:

\begin{tabular}{|l|l|l|l|l|}
\hline Station & Time & Occupancy & $\begin{array}{l}\text { Passing train } \\
\text { observation } \\
\text { (Time) }\end{array}$ & $\begin{array}{l}\text { Unusual } \\
\text { circumstances }\end{array}$ \\
\hline Harlem/Lake & & & & \\
\hline Oak Park & & & & \\
\hline Ridgeland & & & & \\
\hline Austin & & & & \\
\hline Central & & & & \\
\hline & & & & \\
\hline Laramie & & & & \\
\hline Cicero & & & & \\
\hline & & & & \\
\hline $\begin{array}{l}\text { Conservatory- } \\
\text { Dentral Park }\end{array}$ & & & & \\
\hline & & & & \\
\hline
\end{tabular}


APPENDIX B (continued)

\begin{tabular}{|l|l|l|l|l|}
\hline Station & Time & Occupancy & $\begin{array}{c}\text { Passing train } \\
\text { observation } \\
\text { (Time) }\end{array}$ & $\begin{array}{l}\text { Unusual } \\
\text { circumstances }\end{array}$ \\
\hline California & & & & \\
\hline Ashland & & & & \\
\hline Morgan & & & & \\
\hline Clinton & & & & \\
\hline Clark/Lake & & & & \\
\hline State/Lake & & & & \\
\hline & & & & \\
\hline Randolph/Wabash & & & & \\
\hline Indiana & & & & \\
\hline Madison/Wabash & & & & \\
\hline & & & & \\
\hline & & & & \\
\hline Adams/Wabash & & & & \\
\hline
\end{tabular}


APPENDIX B (continued)

\begin{tabular}{|l|l|l|l|l|}
\hline Station & Time & Occupancy & $\begin{array}{l}\text { Passing train } \\
\text { observation } \\
\text { (Time) }\end{array}$ & $\begin{array}{l}\text { Unusual } \\
\text { circumstances }\end{array}$ \\
\hline 47th & & & & \\
\hline 51 & & & & \\
\hline Garfield & & & & \\
\hline Halsted & & & & \\
\hline Ashland/63rd & & & & \\
\hline & & & & \\
\hline King Drive & & & & \\
\hline & & & & \\
\hline
\end{tabular}


APPENDIX B (continued)

\section{Orange Line Observation Instruction}

\section{Occupancy categorization}

Please observe the number of riders on the car when leaving the station. Circle one of the categories:

- LOW: Many open seats on the car, though a few riders may be standing.

- MEDIUM: Most of the seats are full and some riders are standing.

- HIGH: Most of the seats are full and many riders are standing (crowded).

\section{2. $\quad$ Time}

Please record the time indicated on the digital clock when doors are opened at each station. The time will be recorded to the minute, such as 9:31.

\section{3. $\quad$ Passing train observation}

Please record the time when another train passes by. The time will be recorded to the minute, such as 9:31.

\section{Surrounding environment}

Recording the time when the train change from being elevated to on ground between Pulaski and Midway.

\section{Unusual circumstances}

Please record unusual circumstances that could increase the noise level on the train. For example, note if people are talking loudly or playing music.

\section{6. $\quad$ Train car model}

Please note if the train car has center-facing seats (write "center"). 
APPENDIX B (continued)

\section{Direction: Orange line to Midway}

Train car model:

Date:

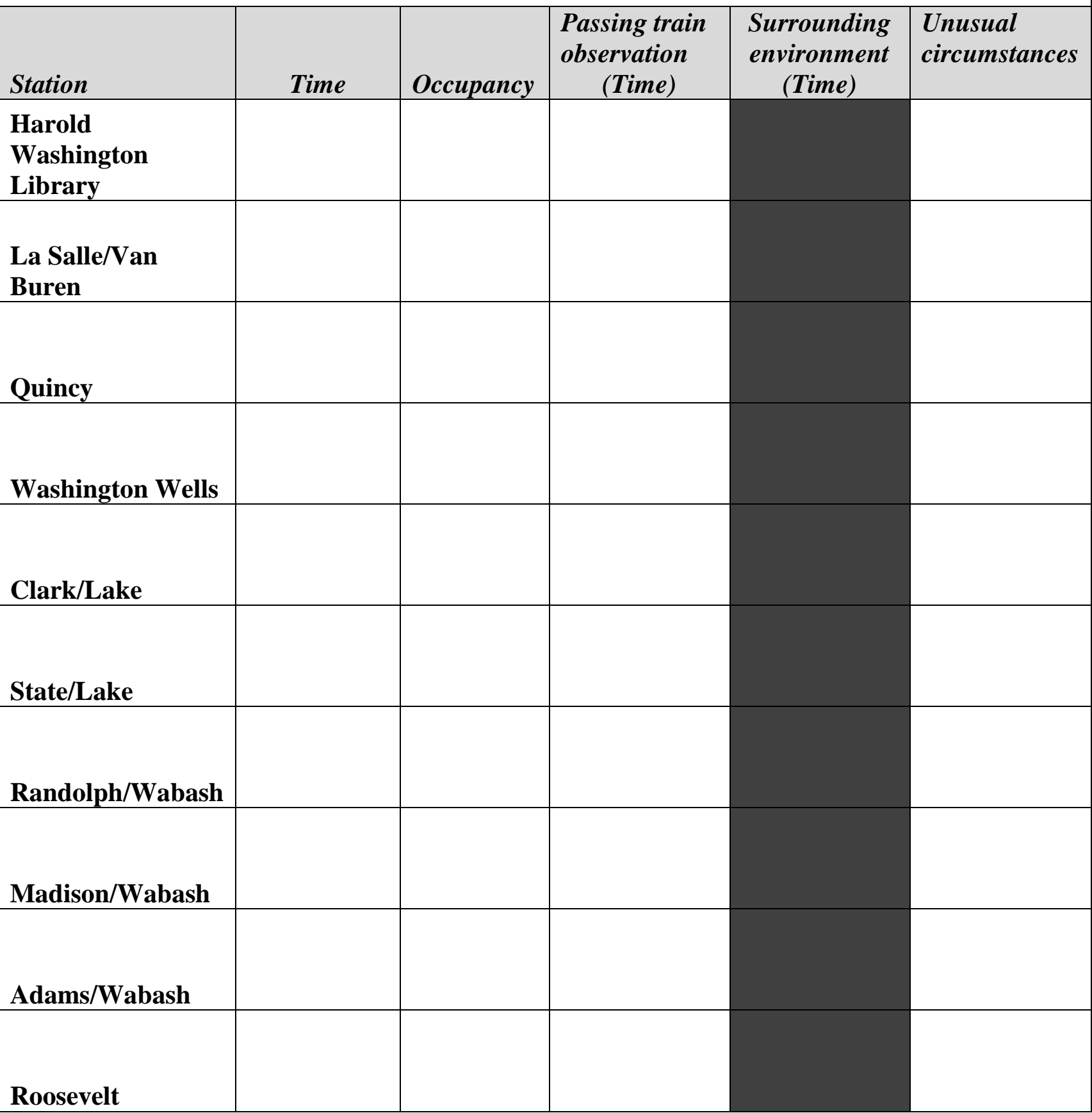


APPENDIX B (continued)

\begin{tabular}{|l|l|l|l|l|l|}
\hline Station & Time & Occupancy & $\begin{array}{c}\text { Passing train } \\
\text { observation } \\
\text { (Time) }\end{array}$ & $\begin{array}{l}\text { Surrounding } \\
\text { environment } \\
\text { (Time) }\end{array}$ & $\begin{array}{l}\text { Unusual } \\
\text { circumstances }\end{array}$ \\
\hline Halsted & & & & \\
Ashland & & & & \\
\hline 35th/Archer & & & & \\
\hline Western & & & & \\
\hline Kedzie & & & & & \\
\hline & & & & & \\
\hline Pulaski & & & & & \\
\hline & & & & & \\
\hline
\end{tabular}




\section{APPENDIX B (continued)}

\section{E. Purple Line Observation Instruction}

\section{Occupancy categorization}

Please observe the number of riders on the car when leaving the station. Circle one of the categories:

- LOW: Many open seats on the car, though a few riders may be standing.

- MEDIUM: Most of the seats are full and some riders are standing.

- HIGH: Most of the seats are full and many riders are standing (crowded).

\section{2. $\quad \underline{\text { Time }}$}

Please record the time indicated on the digital clock when doors are opened at each station. The time will be recorded to the minute, such as 9:31.

\section{3. $\quad$ Passing train observation}

Please record the time when another train passes by. The time will be recorded to the minute, such as 9:31.

\section{Surrounding environment}

Recording the time when the train change from being elevated to on ground between

\section{Central and Linden.}

\section{Unusual circumstances}

Please record unusual circumstances that could increase the noise level on the train. For example, note if people are talking loudly or playing music.

\section{6. $\quad$ Train car model}

Please note if the train car has center-facing seats (write "center"). 
APPENDIX B (continued)

\section{Direction: Purple line to Linden}

Train car model:

Date:

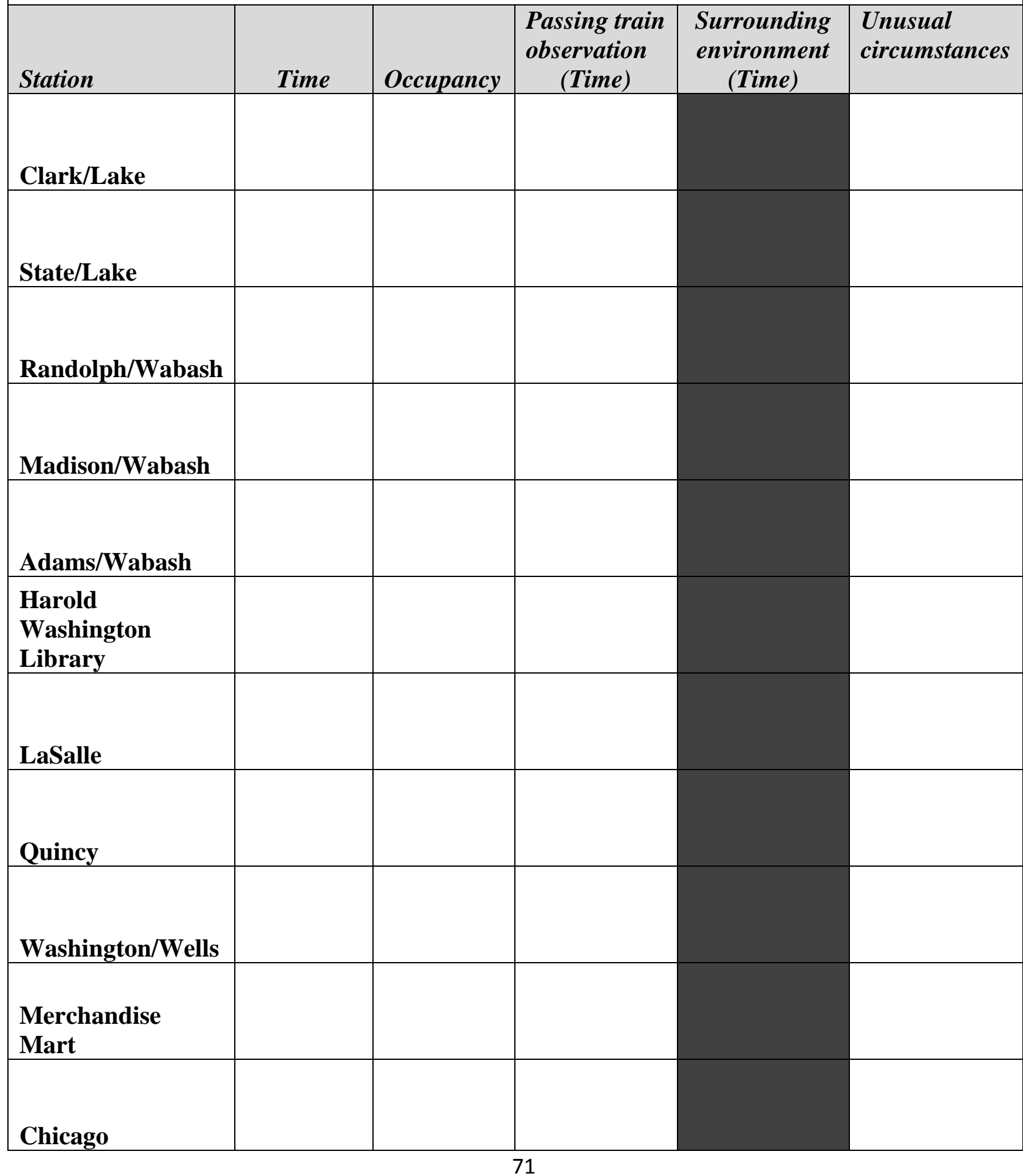


APPENDIX B (continued)

\begin{tabular}{|l|l|l|l|l|l|}
\hline Station & Time & Occupancy & $\begin{array}{c}\text { Passing train } \\
\text { observation } \\
\text { (Time) }\end{array}$ & $\begin{array}{l}\text { Surrounding } \\
\text { environment } \\
\text { (Time) }\end{array}$ & $\begin{array}{l}\text { Unusual } \\
\text { circumstances }\end{array}$ \\
\hline Armitage & & & & \\
\hline Fullerton & & & \\
\hline Diversey & & & \\
\hline Wellington & & & \\
\hline Belmont & & & \\
\hline Howard & & & \\
\hline South Boulevard & & & & \\
\hline & & & & \\
\hline Dain & & & & \\
\hline & & & \\
\hline
\end{tabular}


APPENDIX B (continued)

\begin{tabular}{|l|l|l|l|l|l|}
\hline Station & Time & Occupancy & $\begin{array}{l}\text { Passing train } \\
\text { observation } \\
\text { (Time) }\end{array}$ & $\begin{array}{l}\text { Surrounding } \\
\text { environment } \\
\text { (Time) }\end{array}$ & $\begin{array}{l}\text { Unusual } \\
\text { circumstances }\end{array}$ \\
\hline Central & & & & & \\
\hline Linden & & & & & \\
\hline
\end{tabular}




\section{APPENDIX B (continued)}

\section{F. $\quad$ Red Line Observation Instruction}

1. Occupancy categorization

Please observe the number of riders on the car when leaving the station. Circle one of the categories:

- LOW: Many open seats on the car, though a few riders may be standing.

- MEDIUM: Most of the seats are full and some riders are standing.

- HIGH: Most of the seats are full and many riders are standing (crowded).

\section{2. $\quad \underline{\text { Time }}$}

Please record the time indicated on the digital clock when doors are opened at each station. The time will be recorded to the minute, such as 9:31.

\section{3. $\quad$ Passing train observation}

Please record the time when another train passes by. The time will be recorded to the minute, such as 9:31.

\section{Surrounding environment}

Recording the time when the train changes from GROUND to be ELEVATED between SOX-35TH and CERMAK/CHINATOWN.

Recording the time when the train changes from being ELEVATED to TUNNEL between CERMAK/CHINATOWN and ROOSEVELT.

Recording the time when the train changes from TUNNEL TO being ELEVATED between NORTH/CLYBOURN and FULLERTON.

\section{Unusual circumstances}

Please record unusual circumstances that could increase the noise level on the train. For example, note if people are talking loudly or playing music.

\section{6. $\quad$ Train car model}

Please note if the train car has center-facing seats (write "center"). 
APPENDIX B (continued)

\section{Direction: Red line from 95th to Howard}

Train car model:

Date:

\begin{tabular}{|c|c|c|c|c|c|}
\hline Station & Time & Occupancy & $\begin{array}{c}\text { Passing train } \\
\text { observation } \\
\quad \text { (Time) }\end{array}$ & $\begin{array}{l}\text { Surrounding } \\
\text { environment } \\
\text { (Time) }\end{array}$ & $\begin{array}{l}\text { Unusual } \\
\text { circumstances }\end{array}$ \\
\hline 95th/Dan R & & & & & \\
\hline 87th & & & & & \\
\hline 79th & & & & & \\
\hline 69th & & & & & \\
\hline 63rd & & & & & \\
\hline Garfield & & & & & \\
\hline $47^{\text {th }}$ & & & & & \\
\hline Sox-35th & & & & & \\
\hline $\begin{array}{l}\text { Cermak- } \\
\text { Chinatown }\end{array}$ & & & & & \\
\hline Roosevelt & & & & & \\
\hline
\end{tabular}


APPENDIX B (continued)

\begin{tabular}{|l|l|l|l|l|l|}
\hline Station & Time & Occupancy & $\begin{array}{c}\text { Passing train } \\
\text { observation } \\
\text { (Time) }\end{array}$ & $\begin{array}{c}\text { Surrounding } \\
\text { environment } \\
\text { (Time) }\end{array}$ & $\begin{array}{l}\text { Unusual } \\
\text { circumstances }\end{array}$ \\
\hline Harrison & & & & \\
\hline Jackson & & & & \\
\hline Monroe & & & & \\
\hline Lake & & & & \\
\hline Grand/State & & & & & \\
\hline Chicago/State & & & & & \\
\hline Sheridan & & & & & \\
\hline Clark/Division & & & & & \\
\hline & & & & & \\
\hline North/Clybourn & & & & & \\
\hline & & & & & \\
\hline
\end{tabular}


APPENDIX B (continued)

\begin{tabular}{|l|l|l|l|l|l|}
\hline Station & Time & Occupancy & $\begin{array}{c}\text { Passing train } \\
\text { observation } \\
\text { (Time) }\end{array}$ & $\begin{array}{c}\text { Surrounding } \\
\text { environment } \\
\text { (Time) }\end{array}$ & $\begin{array}{l}\text { Unusual } \\
\text { circumstances }\end{array}$ \\
\hline Wilson & & & & \\
\hline Lawrence & & & & \\
\hline Argyle & & & & \\
\hline Berwyn & & & & \\
\hline Bryn Mawr & & & & \\
\hline Thorndale & & & & & \\
\hline Granville & & & & & \\
\hline Loyola & & & & \\
\hline Morse & & & & \\
\hline & & & & \\
\hline
\end{tabular}




\section{APPENDIX B (continued)}

\section{G. Pink Line Observation Instruction}

\section{Occupancy categorization}

Please observe the number of riders on the car when leaving the station. Circle one of the categories:

- LOW: Many open seats on the car, though a few riders may be standing.

- MEDIUM: Most of the seats are full and some riders are standing.

- HIGH: Most of the seats are full and many riders are standing (crowded).

\section{2. $\quad \underline{\text { Time }}$}

Please record the time indicated on the digital clock when doors are opened at each station. The time will be recorded to the minute, such as 9:31.

\section{Passing train observation}

Please record the time when another train passes by. The time will be recorded to the minute, such as 9:31.

\section{4. $\quad$ Surrounding environment}

Recording the time when the train changes from being elevated to on ground between

Pulaski and Kostner.

\section{Unusual circumstances}

Please record unusual circumstances that could increase the noise level on the train. For example, note if people are talking loudly or playing music.

\section{Train car model}

Please note if the train car has center-facing seats (write "center"). 
APPENDIX B (continued)

\section{Direction: Pink line to 54th/ Cermak}

Train car model:

Date:

\begin{tabular}{|c|c|c|c|c|c|}
\hline Station & Time & Occupancy & $\begin{array}{l}\text { Passing train } \\
\text { observation } \\
\text { (Time) }\end{array}$ & $\begin{array}{c}\text { Surrounding } \\
\text { environment } \\
\text { (Time) }\end{array}$ & $\begin{array}{l}\text { Unusual } \\
\text { circumstances }\end{array}$ \\
\hline Clark/Lake & & & & & \\
\hline State/Lake & & & & & \\
\hline Randolph/Wabash & & & & & \\
\hline Madison/Wabash & & & & & \\
\hline Adams/Wabash & & & & & \\
\hline $\begin{array}{l}\text { Harold } \\
\text { Washington } \\
\text { Library }\end{array}$ & & & & & \\
\hline LaSalle & & & & & \\
\hline Quincy & & & & & \\
\hline Washington/Wells & & & & & \\
\hline Clinton & & & & & \\
\hline
\end{tabular}


APPENDIX B (continued)

\begin{tabular}{|c|c|c|c|c|c|}
\hline Station & Time & Occupancy & $\begin{array}{c}\text { Passing train } \\
\text { observation } \\
\text { (Time) }\end{array}$ & $\begin{array}{c}\text { Surrounding } \\
\text { environment } \\
\text { (Time) }\end{array}$ & $\begin{array}{l}\text { Unusual } \\
\text { circumstances }\end{array}$ \\
\hline Morgan & & & & & \\
\hline Ashland & & & & & \\
\hline Polk & & & & & \\
\hline 18th & & & & & \\
\hline Damen & & & & & \\
\hline Western & & & & & \\
\hline California & & & & & \\
\hline Kedzie & & & & & \\
\hline Central Park & & & & & \\
\hline Pulaski & & & & & \\
\hline Kostner & & & & & \\
\hline Cicero & & & & & \\
\hline 54th/Cermak & & & & & \\
\hline
\end{tabular}




\section{VITA}

NAME: $\quad$ Linh Thuy Phan

EDUCATION: $\quad$ BS, Public Health, Hanoi School of Public Health, Hanoi, Vietnam, 2012.

MS, Public Health—Environmental and Occupational Health Sciences,

University of Illinois at Chicago, Chicago, Illinois, 2015.

HONORS: $\quad$ Vietnam Education Foundation Fellowship, University of Illinois at Chicago, Chicago, Illinois, 2013-2015.

AWARDS: $\quad$ American Industrial Hygiene Foundation Scholarship, 2014-2015.

Michael Bruton Workplace Safety Foundation Scholarship, University of Illinois at Chicago, Chicago, Illinois, 2015.

PROFESSIONAL American Industrial Hygiene Association MEMBERSHIP

PUBLICATIONS: $\quad$ L. T. Phan, and H. T. Le. "Impacts of Climate Change on Child Health." Vietnam Public Health Association Journal 27, no. 27 (2013): 4-10.

H. T. Le, K. L. Tran, and L. T. Phan. "Selection of Pictorial Health Warning on Cigarette Packs in Vietnam."Vietnam Public Health Association Journal 30, no. 30 (2014): 52-59. 